\title{
Por uma vida sem barragens: corpos, território e o papel da autodeterminação na desnaturalização da violência
}

\section{Léa Tosold}

Maria Sibylla Merian Centre Conviviality-Inequality in Latin America (Mecila) | São Paulo, SP, Brasil

leatosold@gmail.com | https://orcid.org/0000-0003-0756-3132

Partindo do emblemático contexto de (r)existência munduruku e ribeirinha à tentativa de imposição das barragens de São Luiz e Jatobá, na bacia do rio Tapajós, entre 2013 e 2015, procuro traçar uma perspectiva analítica capaz de apreender como o caráter substantivo da lógica de progresso/desenvolvimento, identificada com o Estado, vem a tomar corpo nos embates cotidianos, envolvendo diferentes atores sociais. Identifico dois modos distintos por meio dos quais tal lógica opera: o rumor - que, como coloca Veena Das, caracteriza a efetivação do que é apenas potencialidade - e a não performatividade - em que, diversamente, de acordo com Sara Ahmed, a enunciação vem a substituir a ação. Conforme sugiro, a persistência dos povos munduruku e ribeirinho em seu próprio processo de autodeterminação cole(a)tiva mostrou-se fundamental a fim de possibilitar a desnaturalização da violência subjacente à lógica de progresso/ desenvolvimento e permitir o florescimento de modos específicos de (r)existências que Ihe fizessem frente, mesmo sob enorme disparidade em termos de correlação de forças.

For a life without dams: bodies, territory and the role of self-determination in the denaturalization of violence

ABSTRACT Departing from the emblematic munduruku and riverside peoples resistance context in face of the systematic attempts of imposing the São Luiz and Jatobá dams in the Tapajós river basin, Amazonia, between 2013 and 2015, I aim at drawing an analytical perspective able to grasp how the substantive character of the logic of progress/development - identified with the state — is embodied in ordinary life by multiple social actors. I identify two different modes through which this logic operates: rumor — which, as pointed out by Veena Das, characterizes the realization of what is only potentiality - and non-performative - in which, according to Sara Ahmed, the speech act comes to stand in for the effects. I suggest that the persistence of the munduruku and the riverside peoples in their own self-determination processes was fundamental in order to enable the denaturalization of violence underlying the logic of progress/development, and so to expose its intentionality before the mega-enterprise became a fait accompli, allowing specific fortunate modes of resistance to flourish, even under enormous power balance disparities.

\section{KEYWORDS}

Collective Self-Determination, Critic of Progress/Development, Middle Tapajós, Resistance,

Munduruku, Riverside Population 
Nós, povo Munduruku, aprendemos com nossos ancestrais que devemos ser fortes como a grande onça pintada e nossa palavra deve ser como o rio, que corre sempre na mesma direção. O que nós falamos vale mais que qualquer papel assinado. Assim vivemos há muitos séculos nesta terra. O governo brasileiro age como a sucuri gigante, que vai apertando devagar, querendo que a gente não tenha mais força e morra sem ar. Vai prometendo, vai mentindo, vai enganando.

Comunicado ao governo brasileiro emitido pelo povo munduruku, 3 nov. 2014

\section{ABERTURA}

Se o Tapajós, hoje, continua sendo o único grande rio da Amazônia livre de barragens, isso se deve, sem sombra de dúvidas, à (r)existência' ferrenha dos povos da floresta na região. No que segue, procuro, a partir de meu engajamento como ativista ${ }^{2}$, traçar uma perspectiva analítica para a apreensão dos conflitos criados pela imposição da lógica de progresso/desenvolvimento referente ao projeto de construção das barragens de São Luiz e Jatobá, no Médio Tapajós ${ }^{3}$ - as quais, se efetivadas, viriam a inundar territórios habitados pelos povos munduruku e ribeirinho ${ }^{4}$, afetando de modo irreversível suas vidas. Foco minha análise no desdobrar de significativos acontecimentos na região entre 2013 e 2015, período marcado pelo incisivo intento, por parte do Estado e da iniciativa privada, de sobreimpor esse megaempreendimento como fato consumado.

A meu ver, a força da (r)existência dos povos munduruku e beiradeiro reside, sobretudo, em seu potencial de auto-organização cole(a)tiva e (pro)positiva, a partir de seus próprios termos. Posto de outro modo, sua (r)existência, acredito, não emana de uma posição meramente reativa, limitada à denúncia do não cumprimento de leis e tratados - seja da constituição brasileira, seja da Convenção 169 da Organização Internacional do Trabalho (OIT) — por parte do Estado: em vez de Ihes propor "correções" ou "ajustes" — correndo, com isso, o risco de ficarem reféns do modus operandi de tais normativas -, esses povos, diferentemente, expõem de forma patente os limites, quando não a má-fé, que Ihes são inerentes. Conforme argumento, tal potencial de desnaturalização da norma hegemônica, capaz de desencadear modos de (r)existência im-previsíveis e co-moventes - revertendo o quadro, mesmo sob enorme disparidade em termos de correlação de forças, em favor dos povos da floresta - decorre, justamente, do empenho primordial e cotidiano dos povos munduruku e ribeirinho em seus modos próprios de organização social, política e econômica. Assim, podem não somente avaliar e lidar estrategicamente com as normativas, os discursos e as ações do governo e da iniciativa privada com base em uma perspectiva que lhes é própria, mas também instaurar, em seu lugar, uma maneira fundamentalmente distinta de atuar.
1) Uso o termo (r)existência a fim de ressaltar que, em geral, o que viabiliza a resistência é, sobretudo, a "existência"” a partir de referenciais próprios. Com isso, procuro chamar a atenção para a importância de modos de atuação cole(a) tiva que não sejam exclusiva nem primordialmente de oposição em relação à norma dominante - visto que, desse modo, correriam o risco de mantê-la como único referente.

2 | Fiz parte, na condição de ativista, do Comitê Paulista de Solidariedade à Luta pelo Tapajós (Comtapajós), coletivo autônomo que atuou à época, visando a apoiar os processos de (r)existência dos povos mundurukue ribeirinho à construção de barragens em seus territórios.

3 | Este artigo é construído com base no "Primeiro Movimento" de minha tese de doutorado, intitulada "Autodeterminação

em três movimentos: a politização de diferenças sob a perspectiva da (des) naturalização da violência"

(Tosold, 2018). Hesitei acerca da publicação dos argumentos que seguem, de modo desvinculado da tese como um todo, pois se trata de um trabalho de teoria política com inspiração antropológica que, a partir de uma perspectiva acadêmica engajada, é inspirado na luta dos povos mundurukue ribeirinho da região — não se trata, portanto, de uma tese sobre esses povos (o que, inclusive, demandaria aprovação prévia, de acordo com os preceitos munduruku e ribeirinho, para vir a ter lugar). No entanto, dado o contexto atual em que estamos vivendo, trazer à tona o rico processo de (r)existência protagonizado pelos povos mundurukue ribeirinho no período em questão sob a perspectiva analítica proposta parece-me premente: por um lado, o artigo chama a atenção para conflitos que continuam agudizandose na região, ameaçando tanto aos povos da floresta quanto aos seus territórios (e, consequentemente, a existência de todxs), de modo a suscitar a importância de apoio aos povos munduruku e ribeirinho em defesa de seus territórios na atualidade; por outro lado, além de documentar parte do processo de (r)existência munduruku e ribeirinha, a perspectiva 
No que segue, focarei três acontecimentos-chave do processo de (r)existência munduruku e ribeirinha no período: a ocupação do canteiro de obras da usina de Belo Monte; a elaboração do Protocolo de Consulta Munduruku e o processo de autodemarcação do território Daje Kapap Eypi (Sawré Muybu).

A fim de evidenciar como tais acontecimentos colocam em xeque a norma hegemônica, desnaturalizando-a, faz-se imprescindível, antes e ao longo do argumento, tecer algumas considerações acerca do modus operandi de sobreimposição da lógica de progresso/desenvolvimento vinculada ao Estado na conjuntura específica dos embates em torno da construção de barragens no Médio Tapajós. Conforme identifico, há dois modos distintos por meio dos quais o "poder distante, mas implacável (overwhelming)" da lógica de progresso/desenvolvimento é trazido "para a vida cotidiana" (Das, 2007:163), naturalizando-se: o rumor (Das, 2007) — que caracteriza a efetivação do que é apenas potencialidade - , e a não performatividade (Ahmed, 2012), em que, diversamente, a enunciação vem a substituir a ação.

\section{RUMOR: O PRENÚNCIO DAS HIDRELÉTRICAS COMO PRESENÇA}

Talvez não haja outro lugar no mundo em que estejam concentradas, a um só tempo, tantas das mais diversas formas de expropriação, despojo e violência vigentes na atualidade, como é o caso da Amazônia: tal qual coloca o arqueólogo Raoni Valle, estaríamos presenciando "a reedição de práticas históricas de colonização" não só na região amazônica, mas também em "todas as Américas" (Castro, 2015). Trata-se, como sugere Veena Das, de um histórico de violências que segue em aberto e tão presente, o qual remonta desde ao menos as expedições missionárias e bandeirantes: a exploração da borracha, da madeira, de areia, dos minérios; a construção de megaobras - como portos graneleiros, ferrovias, rodovias, hidrovias - e suas nefastas consequências; a criação de gado e soja; as queimadas; a grilagem de terras... São tantas as frentes de exploração que se somam desde a intrusão colonial, tal qual "uma catástrofe única" que "acumula incansavelmente ruína sobre ruína e as dispersa a nossos pés" (Benjamin, 2010 [1940]: 226), formando um mosaico de conflitos aos quais se acrescem as planejadas hidrelétricas de São Luiz e Jatobá: elas mesmas potencializadoras de uma série de formas de expropriação violenta sob o signo de progresso/desenvolvimento na região - contra as quais, ao longo de séculos, os povos da floresta seguem fazendo frente de (r)existência.

\footnotetext{
Nós vivemos o tempo dos antigos patrões, do carrancismo e do aviamento da borracha. Vencemos as dificuldades vindas com o fim 'dos tempos da seringa'. Encontramos um jeito de viver quando acabou o comércio das 'peles de gatos'. Sobrevivemos à chegada — e ao fim - dos garimpos, à malária, à contaminação do rio por mercúrio e a todas as outras dificuldades que apareceram. Muitas das famílias de nosso grupo foram expulsas pelo
}

analítica aqui apresentada pode também vir a ser relevante para a configuração de processos cole(a)tivos de (r)existência, inspirando, mais amplamente, ações con-juntas que visem a evitar a (re)produção da norma hegemônica. A versão fina deste artigo deve, muito às trocas com Marilia M. Pisani, Álvaro Okura, Nayana Fernández e Mariana Ribeiro.

$4 \mid$ O povo munduruku é formado por cerca de $13 \mathrm{mil}$ pessoas distribuídas em mais de 210 aldeias por 850 quilômetros ao longo da bacia do rio Tapajós, no Oest do Pará, região que ocupa tradicionalmente, ao longo de séculos (cf. Fundação Nacional do Índio, 2013). O povo beiradeiro encontra-se na região do Médio Tapajós desde os "tempos da borracha" as localidades de Montanha e Mangabal e de Pimental e São Francisco são constituídas por cerca de 250 famílias que, como o povo munduruku, vivem do rio e da terra, dos quais tiram seu sustento (por meio da caça, da roça, da pesca), de modo comunal. Além de profundos conhecedores da floresta, sua presença é o principal fator para que esta permaneça 'em pé' (cf. Instituto Brasileiro do Meio Ambiente, 2014). 
próprio governo federal com muita violência, nos anos 1970, com a criação do Parque
Nacional da Amazônia, onde também era nosso território. Mas nós resistimos também
a isso e nos juntamos rio acima, fora dos limites do Parque, e continuamos nossa vida.
(Associação de Moradores das Comunidades de Montanha e Mangabal, 2013)

Nesse contexto, a notícia das barragens de São Luiz e Jatobá — mais um dos megaprojetos "desenvolvimentistas" planejados na Amazônia - emerge como o prenúncio de uma catástrofe que é associada ao Estado: seja diretamente, como reconhecido protagonista de processos de violência ligados à implantação de empreendimentos dessa ordem; seja indiretamente, como desencadeador de uma série de alterações na vida cotidiana, que presentificam as hidrelétricas antes mesmo de elas chegarem — como a especulação imobiliária e o aumento exponencial da população nos centros urbanos; a intensificação da exploração da madeira; ou, até mesmo, o aparecimento de organizações não governamentais, que passam a atuar localmente a partir da premissa do suposto iminente advento das megausinas. Nesse sentido, inclusive a minha chegada, na condição de ativista apoiadora dos processos de (r)existência à efetivação das barragens de São Luiz e Jatobá, já se configura como desdobramento da presença desse empreendimento em potencial.

O rumor, como aponta Das, refere-se ao potencial de se produzir eventos "no próprio ato de falar" (2007: 108). Trata-se da força perlocucionária da linguagem "sua capacidade de fazer algo dizendo algo", de modo que as palavras deixam de ser "um meio de comunicação" para se transformar em "um instrumento de força" (Ibidem, 1998: 117). O rumor, "concebido para ser espalhado", contagia todo o tecido social a ponto de não se poder traçar, de modo transparente, a fonte da qual emana o que Das denomina "falta de assinatura" (lack of signature) (Ibidem, 1998: 125) e tem, como efeito, a naturalização das violências que implica (Ibidem, 1998: 117; Matebeni, 2017). Desse modo, é como se o rumor não propriamente "causa[sse] o acontecimento dos eventos, mas os autoriza[sse]" (Idem, 2007: 106). Conforme argumento neste artigo, a lógica de progresso/desenvolvimento associada ao Estado, como rumor, repercute, no contexto em questão, no sentido de presentificar as hidrelétricas como "fato consumado" antes mesmo de que venham a ser efetivadas, inscrevendo-se sobre as memórias de eventos similares já ocorridos na região (cf. Das, 2007: 121).

Assim, tal qual um rumor, no sentido atribuído por Das, a vinda do progresso/ desenvolvimento, con-fundida com a chegada do próprio Estado, vai sub-repticiamente se instalando, de maneira contraditória e por meio de diversos agentes no corpo social, de modo a alterar substancialmente os modos de vida das populações locais. Com efeito, torna-se cada vez mais real a presença do empreendimento antes mesmo que ele aconteça - o que vem a corroborar no sentido de desmobilizar ex ante as possibilidades de (r)existência, visto que as hidrelétricas adquirem um caráter de suposta inevitabilidade.

Rev. antropol. (São Paulo, Online) | v. 63 n. 3: e178182 | USP, 2020 
Embora intensificadas entre 2013 e 2015 na região, ações que geram rumores corroborando com a lógica de progresso/desenvolvimento, presentificando as hidrelétricas de São Luiz e Jatobá antes mesmo de que sua viabilidade tenha sequer sido verificada, não são de hoje. Data ao menos da década de 1980 (Loures, 2016: 6) a visita de pesquisadorxs à região e, conforme constatado pela população ribeirinha de Pimental, técnicxs da Eletrobras e da Eletronorte rondam a região há cerca de uma década (Barros, 2012). Soma-se a isso a memória histórica de eventos similares na Amazônia, como a da catastrófica efetivação da usina hidrelétrica de Balbina, na região de Presidente Figueiredo, cuja operação teve início em 1989 (cf. Fearnside, 2015a: 97-125), bem como a do reiterado uso, nos últimos anos, do instrumento jurídico de suspensão da segurança, criado durante a ditadura militar, a fim de permitir a efetivação de megaempreendimentos a despeito de toda sorte de irregularidades - como nos casos da construção das hidrelétricas de Jirau e Santo Antônio, no rio Madeira, de Belo Monte, no rio Xingu, e, mais recentemente, na própria bacia do Tapajós, da usina de São Manoel, no rio Teles Pires ${ }^{5}$.

Há, assim, larga história, no contexto amazônico, de sobreimposição de megaempreendimentos, como é o caso de hidrelétricas de grande porte, em meio a um sem-número de distintos processos de desterritorialização que seguem configurando-se, ao longo do tempo, na região - visando, em geral, à exploração e ao "manejo" de "recursos" - com todo o rastro de violências que constituem. Trata-se de um contexto que traz, consigo, uma "memória social", como bem coloca Das, a qualé, em larga medida, "composta por histórias sociais incompletas ou interrompidas" (1998: 115), dados os processos violentos de desterritorialização justificados sob a rubrica do progresso/desenvolvimento. Isso gera, com efeito, que a população local leve a sério os rumores de possível chegada das barragens de São Luiz do Tapajós e Jatobá: agregam-se, à presença dessa memória social, os diversos fatores e intentos de presentificação de tais megaempreendimentos já muito antes de sua efetivação, ao mesmo tempo em que estratégias de (r)existência e organização con-junta vão sendo (re)criadas a fim de lidar com a situação.

\section{NÃO PERFORMATIVIDADE E (R)EXISTÊNCIA}

A temporalidade espacializada dos povos da floresta contrasta com a pressa da lógica de progresso/desenvolvimento que procura, de todas as formas, e a qualquer custo, acelerar e presentificar a sobreimposição das barragens de São Luiz e Jatobá. Nesse sentido, os povos munduruku e ribeirinho emergem como suposto "entrave".

O governo, com o seu projeto, não traz 'progresso nem desenvolvimento', só traz morte. E a população indígena não tem direito de contestar esse tipo de violação. E quando nos manifestamos indignados, com toda razão e com direitos, o governo diz: 'estão atrapalhando'.
$5 \mid$ O instrumento jurídico conhecido por suspensão de segurança foi introduzido em 1964, com o objetivo de suspender ordens judiciais movidas contra o poder público que são entendidas, pelo Tribunal Superior, como ameaça à ordem, à segurança, à saúde e à economia públicas. No caso das hidrelétricas em questão, como aponta Luísa Pontes Molina, a suspensão de segurança tem sido utilizada "para expressar uma noção de que, estando o Brasil em uma 'crise na oferta de energia', as hidrelétricas na Amazônia são indispensáveis, e a interrupção do licenciamento ou das obras dessas usinas, uma ilegalidade" (2017: 30). 


\begin{abstract}
Nós, indígenas, não estamos atrapalhando ninguém. Porque não somos nós que estamos indo a Brasília para tomar as terras dos pariwat e matar. Nem vamos lá para desrespeitar os seus direitos e não invadimos os seus territórios. Como dizem que estamos atrapalhando se foram eles mesmos que fizeram essa tal de Lei para ser obedecida e cumprida e não estão nem respeitando o que eles mesmos escreveram? (Povo Munduruku, 2015b)
\end{abstract}

Com efeito, é possível a meu ver identificar, como principal estratégia da "frente estatal-empresarial" (Segato, 2016) que encarna a lógica de progresso/desenvolvimento, a tentativa sistemática e deliberada de apagamento ou minimização da existência dos povos tradicionais da região, ao mesmo tempo em que supostamente se cumpre, de modo não performativo (Ahmed, 2012), as prerrogativas formais de consulta a esses povos. Trata-se de uma estratégia que nega o conflito e é primordialmente ambígua, em que o que se fala e o que se faz distanciam-se de tal modo a confundir e, assim, desencadear a presentificação dos megaempreendimentos a um ponto 'irreversível', ainda antes que se possa organizar, de modo consistente, qualquer frente de (r)existência.

Se o rumor caracteriza a efetivação do que é apenas potencialidade, a noção de não performatividade, proposta por Sara Ahmed, funciona de modo distinto: diz respeito a como um discurso, ao ser nomeado, pode implicar, justamente, a sua não realização. Nas palavras da escritora feminista antirracista e pesquisadora:

\footnotetext{
Não performativo [non-performative] descreve a "prática reiterativa e citacional por meio da qual o discurso" não produz "os efeitos que nomeia" (BUTLER; 1993, p. 2). No mundo do não performativo, nomear é não gerar efeito (...) Em meu modelo do não performativo, a falha do ato de fala em realizar o que nomeia não é uma falha de intenção ou mesmo de circunstância, mas é justamente o que o a to de fala está fazendo. Tais atos de fala são tomados como se fossem performativos (como se gerassem os efeitos que nomeiam), de forma que a nomeação passa a substituir os efeitos. Como resultado, nomear pode ser uma forma de não gerar efeitos. (AHMED, 2012: 117, tradução minha, ênfases no original)
}

Na condição de não performatividade os discursos, por assim dizer, assumem o lugar da própria performance de seu conteúdo, como se "produzissem os efeitos que nomeiam" (Ahmed, 2012: 116). A meu ver, atentar analiticamente para o que está sendo feito (Ahmed, 2012: 8) com base em discursos vinculados ao Estado, no que concerne à mobilização da narrativa de progresso/desenvolvimento no contexto em questão, revela o intento de produção de cumprimento de supostos mecanismos de consulta e participação popular previstos em lei, de maneira não performativa. Nesse sentido, a prerrogativa mesma de consulta pública emergiria como sinal de inclusão (cf. Ahmed, 2012: 65), de modo que sua mera enunciação faria desaparecer o sinal da exclusão, bem como os conflitos estruturais que se 
configuram em campo (cf. Ahmed, 2012: 65). Com base na noção de não performatividade, portanto, procuro apreender analiticamente os mecanismos de naturalização da violência em curso que visam a legitimar, sob a narrativa de progresso/ desenvolvimento, a imposição autoritária de medidas que "passam por cima" dos povos munduruku e ribeirinho sob a aparência de cumprimento de processos de participação popular. Conforme aponto, o caráter (pro)positivo - e não meramente reativo — da (r)existência munduruku e beiradeira permite apreender a violência subjacente ao modus operandi da não performatividade, fazendo-lhe frente a partir de um modo de atuação que vincula o que se fala (conteúdo) e o que se faz (forma).

Ora, os povos da floresta sabem que existem, e que o Estado sabe que eles existem. Sabem, também, como querem ser consultados: por meio do único modo em que isso valeria a pena, que é tendo, efetivamente, poder de veto. O Estado, por sua vez, quer sobreimpor as barragens, sabendo que os povos da floresta estão em contra disso. Sua estratégia, portanto, é a de ignorar, agindo como se não existissem, ao mesmo tempo em que finge consultar - como se incorporar discursivamente a consulta "substituísse" ações que lhe fossem de fato correspondentes —, num jogo burocrático-discursivo que visa a encobrir a violência em curso da sobreimposição das barragens.

Quanto mais rápido se presentificam as hidrelétricas, mais elas se tornam "fato consumado", de modo que as populações passam a estar cada vez mais restritas às regras do jogo igualmente sobreimpostas pelo Estado. Em outras palavras, pretende-se atingir o ponto irreversível, em que a opção dos povos afetados passa a ser, unicamente, a luta pelo mero cumprimento de ilusórias medidas de "compensação" de "impacto", uma vez que o "estrago" já teria sido feito. O próprio modo discursivo hegemônico acerca do processo de consulta já subentende, por princípio, a obra como "fato consumado". Como afirmou expressamente à época Gilberto Carvalho, então ministro da Secretaria-Ceral da Presidência: "A consulta não é deliberativa. Ela deve ser feita para atender demandas, diminuir impactos, mas não é impeditiva [da construção das barragens]" (Fellet, 2014).

O governo, as empreiteiras, o agronegócio, as mineradoras - a lógica do progresso/desenvolvimento - têm pressa. Querem trazer as populações afetadas para dentro das regras burocrático-discursivas de seu jogo, no qual sempre saem ganhando: consultam sobreimpondo, ignoram ao parecer dialogar, agindo "como a sucuri gigante, que vai apertando devagar, querendo que a gente não tenha mais força e morra sem ar. Vai prometendo, vai mentindo, vai enganando" (Povo Munduruku, 2014b). Estar atrelado às regras do jogo da lógica de progresso/desenvolvimento significa adentrar uma condição de eterna "suspensão", à espera do que nunca virá: sejam as "compensações" (que, mesmo quando parcialmente ocorrem, jamais poderiam vir de fato a "compensar" o que, em si, não é passível de "permuta"); seja 
sequer o reconhecimento público de sua dor. Trata-se, fundamentalmente, de um verdadeiro "sequestro" dessas vidas: nada mais, nada menos que a sobreimposição da "morte-em-vida" aos povos em desterritorialização".

Dessa forma, com o disfarce do a parato burocrático-discursivo, procura-se evitar que a indignação surja antes de que as populações estejam à revelia das regras do jogo sobreimpostas - o que poderia tornar muito mais árdua e custosa a sobreimposição de megaprojetos: tanto pela (r)existência capaz de, a partir de referentes próprios, efetivamente ameaçar os planos de consecução desses empreendimentos, quanto pelo que a (r)existência revela, expondo a nu a violência do que aparenta ser o desejável e inevitável caminho rumo ao progresso/desenvolvimento.

Uma vez vendo-se obrigados a atuar exclusivamente dentro do modus operandi da "obra consumada", a indignação dos povos "impactados" emerge de modo domesticado - as pessoas já se encontram desterritorializadas, desnorteadas, em "morte-em-vida”. A indignação é convertida em lamento silenciado pois, com a violência sistematicamenteignorada soba premissa de um discurso deilusórias compensações, não se encontra sequer espaço para a elaboração e o com-partilhamento públicos da dor. A indignação só pode emergir como nostalgia de um passado que parece já não poder ter lugar no presente, como a própria vida das pessoas afetadas ${ }^{8}$. Assim, todo o aparato burocrático-discursivo visa a confundir, a "ir enganando" e minando a possibilidade de (r)existência enquanto a hidrelétrica vai se presentificando, de modo que a violência inerente ao processo de sobreimposição das megaobras permaneça oculta - e siga sendo sistematicamente ignorada — sob a máscara discursiva do supostamente inevitável e desejável progresso/desenvolvimento.

Uma vez explicitados os modos como, via rumor e não performatividade, a lógica do progresso/desenvolvimento sobreimpõe-se em campo, sugiro, no que segue, que a persistência dos povos munduruku e beiradeiro em seu próprio processo de autodeterminação cole(a)tiva mostrou-se fundamental a fim de possibilitar a desnaturalização da violência subjacente à lógica de progresso/desenvolvimento, expondo sua intencionalidade antes de que o megaempreendimento viesse a se tornar "fato consumado", de modo a permitir o florescimento de (r)existências que Ihe fizessem frente.

\section{A OCUPAÇÃO BELO MONTE}

Em janeiro de 2013, tem lugar, na aldeia Sai Cinza (Alto Tapajós), uma assembleia extraordinária do povo munduruku, na qual estiveram presentes cerca de 120 caciques, bem como representantes dos povos kaiabi, apiaká e kayapó. O momento é de grande tensão: havia recém-ocorrido a truculenta Operação Eldorado ${ }^{9}$, coordenada pela Polícia Federal e pela Força de Segurança Nacional, na aldeia Teles Pires (município de Jacareacanga), que culminou na execução sumária de Adenilson Kirixi, bem
6| Elaboro tal conceito mais detidamente em minha tese de doutorado, a partir da distinção sugerida por Walter Benjamin (2011 [1921]) entre "mera vida" — ou, como prefiro nomear, "morte-emvida" — (vinculada à "violência mítica"), e "alma do vivente" (vinculada à "violência divina"). Conforme sugiro, a lógica do progresso/desenvolvimento como modo de naturalização da violência encontra-se intimamente ligada a mecanismos estruturais de desespacialização, que visam a impedir a experiência da relacionalidade e, consequentemente, da própria temporalidade, instaurando o que pode ser caracterizado como "morte-em-vida".

7| É relevante considerar que a enorme (r)existência que a construção da megausina de Belo Monte gerou com imenso custo para a imagem e a credibilidade do governo-contribuiu, em muito, para revelar a violência implicada em tais megaempreendimentos, desnaturalizando sua suposta desejabilidade ou necessidade.

8|É aterrador constatar os elevados índices de depressão e suicídio entre as populações desterritorializadas por megaempreendimentos como nos casos de Belo Monte (cf. Brum, 2014) e da barragem de Sobradinho (PE) (cf. Cribari, 2014) - ou sistematicamente desterritorializadas pelo agronegócio, como é o caso dos povos indígenas, em geral, e do povo guarani-kaiowá, em particular (cf. Carelli, 2017; Elkaim; Nolen, 2017).

9| Supostamente criada para combater o garimpo ilegal, o povo munduruku denunciou a Operação Eldorado como estratégia de intimidação dos moradores da aldeia Teles Pires, que vinham fazendo frente no processo de $(r)$ existência à construção da hidrelétrica de São Manoel, no rio Teles Pires. $O$ ataque à aldeia Teles Pires ocorreu em 7 de novembro de 2012 . 
como em inúmeros feridos, além de ter submetido homens, mulheres e crianças a uma série de práticas de tortura (cf. Fernández, 2014). A operação foi tomada como forma de intimidação ao processo de (r)existência que o povo munduruku vinha protagonizando, tanto com relação à construção da hidrelétrica de São Manuel, no rio Teles Pires ${ }^{10}$, quanto com relação às multifacetadas formas de assédio visando a presentificar as barragens de São Luiz e Jatobá, no Médio Tapajós: desde a presença de pesquisadorxs em território munduruku e ribeirinho, sem nenhum tipo de aviso ou consulta prévia, buscando levantar dados para a série de estudos necessários à viabilização do empreendimento"11, até as tentativas de agentes do governo e da iniciativa privada de simular processos de consulta pública com os povos munduruku e ribeirinho, a fim de cumprir prerrogativas formais vinculadas ao processo de licenciamento da megaobra. Tanto as ameaças quanto o assédio encontravam-se de tal forma intensos naquele momento que, sem terem sido convidadxs, chegaram a aparecer, no local da assembleia, representantes do poder público e da iniciativa privada - xs quais foram, então, convidadxs a se retirar (Sena, 2013).

Em meio a tal situação - que implicava, por um lado, na iminência de conflitos que seguiriam colocando em risco suas vidas, bem como, por outro lado, na possibilidade de serem "enganadxs", como se tivessem sido consultadxs — o povo munduruku elabora uma carta pública, endereçada à então presidenta Dilma Rousseff, apresentando formalmente toda a situação que estavam vivendo, a partir de seu próprio ponto de vista, na tentativa de, com a publicização, evitar o pior. 0 documento incluiu, ainda, a reivindicação de 33 pontos: entre eles, a apuração imediata do assassinato de Adenilson Kirixi e a publicação do Relatório Circunstanciado de Identificação e Delimitação (RCID) da Terra Indígena Sawré Muybu, no Médio Tapajós, pela Fundação Nacional do Índio (Funai), passo necessário para dar prosseguimento à sua demarcação — demanda histórica do povo munduruku, quejá vinha tramitando, desde 2001, nas instâncias formais ${ }^{12}$.

Como se o contexto já não fosse de extrema tensão, tem início, em março de 2013 , a chamada Operação Tapajós, conduzida pelas tropas da recém-criada Companhia de Operações Ambientais da Força Nacional de Segurança Pública'13: cerca de 250 componentes das tropas posicionam-se, de modo ostensivo, em Itaituba, Médio Tapajós, visando a supostamente oferecer "apoio logístico e segurança" a cerca de 80 pesquisadorxs para a realização dos estudos de licenciamento ambiental ${ }^{14}$ que estavam, até aquele momento, suspensos na Justiça por falta de consulta prévia aos povos indígenas potencialmente afetados pela construção das barragens (cf. Cunha, 2013; Conselho Indigenista Missionário, 2013). Havia rumores de que um total de 60 homens seriam deslocados para a aldeia Sawré Muybu, onde viviam, no momento, 132 indígenas (Povo Munduruku, 2013b). Em face dos recentes acontecimentos, e na sequência da malograda Operação Eldorado na aldeia Teles Pires, a Operação Tapajós gera um verdadeiro clima de terror e apreensão para os povos munduruku e ribeirinho do Médio Tapajós.
10|A usina de São Manoel é a primeira do conjunto de hidrelétricas planejado para bacia do Tapajós que vinha sendo levada a cabo - a ela, seguiriam-se as de São Luiz e Jatobá. Não me deterei no processo propriamente dito de (r)existência dos povos da floresta com relação à construção da barragem de São Manoel, o que extrapolaria o enfoque proposto neste artigo.

11 | Para a viabilização formal do licenciamento de um complexo hidrelétrico, é necessária a realização do que se denominam Estudo de Impacto Ambiental (EIA) e Relatório de Impacto Ambiental (Rima). Se o empreendimento hidrelétrico conta como um entre vários planejados em uma mesma bacia hidrográfica, como é o caso da do Tapajós, seria também necessária, a princípio, a realização prévia de estudos de impacto cumulativo — a denominada Ação Ambiental Integrada (AAI). Para maiores detalhes, conferir Fearnside (2015a; 2015b).

12 Com a publicação do RCDI pela Funai no Diário Oficial da União, abre-se formalmente então, para as etapas de contestação, declaração de limites, demarcação física e, finalmente, homologação e registro oficiais da terra indígena. A publicação do relatório, à altura,

encontrava-se, em muito, atrasada, havendo já sido alvo de disputas jurídicas por esse motivo. Os estudos de identificação da terra indígena tinham sido cumpridos em 2008, mas o relatório não havia sido ainda entregue (Aranha; Mota, 2014). O principal fator para a morosidade no processo de demarcação é atribuído à política do então governo, caracterizada pela paralisação do reconhecimento formal de terras indígenas e quilombolas, bem como das chamadas "Unidades de Conservação" (cf. Instituto Socioambiental, 2016).

13 A Companhia de Operações Ambientais da Força Nacional de Segurança Pública, "de caráter preventivo ou repressivo", foi criada a fim de "prestar auxílio à realização de levantamentos e laudos técnicos sobre impactos ambientais negativos", entre outras atribuições. De acordo com a avaliação da 
(...) comunicamos que estamos sendo humilhados e ameaçados pela operação das Forças Armadas do governo criadas pelo decreto 7.957 de 13 de março de 2013 que manda pesquisadores invadirem nossas terras junto com a Polícia Rodoviária Federal, a Polícia Federal, o Exército e a Força Nacional por causa das hidrelétricas do Tapajós, denunciamos que as Forças Armadas estão espalhadas sobre o rio Tapajós, sobre a Transamazônica e nossos territórios intimidando e ameaçando pessoas, nos impedindo de navegar pelos nossos rios e circularmos livremente pelas estradas nas terras e aldeias. Não podemos pescar, trabalhar, tomar banho no rio, caçar, andar livremente e viver nossa vida.

(Povo Munduruku, 2013c)

Além disso, o governo federal ao mesmo tempo anuncia, em nota da Secretaria Nacional de Articulação Social, que já havia preparado e apresentado uma proposta de realização de consulta pública com indígenas do Médio e do Alto Tapajós, para "a pactuação de um plano de consulta, nos termos da Convenção 169 da OIT" (Cunha, 2013). A um só tempo, vê-se um empenho sistemático tanto em sobreimpor os estudos de viabilização das barragens de São Luiz e Jatobá - ignorando a necessidade de consulta aos povos munduruku e ribeirinho para tanto - quanto em sobreimporum processo de consulta pública em moldes já previamente estipulados pelo governo federal - passando por cima da decisão de construção de um protocolo de consulta com a participação ativa dos povos munduruku e beiradeiro.

Éum momento muito difícil, em meio à presença ostensiva das Forças Armadas na região: as informações são desencontradas, reuniões são marcadas e desmarcadas, as pautas são pouco claras ou diferentes das acordadas - todo esse imbróglio gerou enorme insegurança para o povo munduruku, uma vez que temiam que tais encontros viessem a ser utilizados como cumprimento de prerrogativa de consulta nos termos sobreimpostos pelo poder público.

\footnotetext{
Nós, povos indígenas Munduruku do Médio e do Alto Tapajós, estamos na aldeia Sawré Muybu para reafirmar nossa aliança e dizer que o rio Tapajós é um só assim como o povo é um só (...) O governo (...) está tentando dividir o nosso povo Munduruku para conquistar e destruir o rio Tapajós, mas o rio Tapajós não se divide, e o povo Munduruku também não se divide. Nada do que o governo oferece paga toda a riqueza que temos. Não vendemos nosso rio e território, nosso povo, nossa história nem o futuro dos nossos filhos. (Povo Munduruku, 2013c)
}

Procurando demonstrar firmeza no propósito de que o próprio povo munduruku decidisse, por si mesmo, em que termos gostaria de ser consultado, é marcada uma assembleia para o final de abril daquele ano, na aldeia Sai Cinza — e não nos centros urbanos de Itaituba ou Jacareacanga - tendo como uma das pautas a discussão do protocolo de consulta. O governo, convidado para o evento, não comparece. Como ato simbólico, é queimado, durante a assembleia, o modelo de consulta

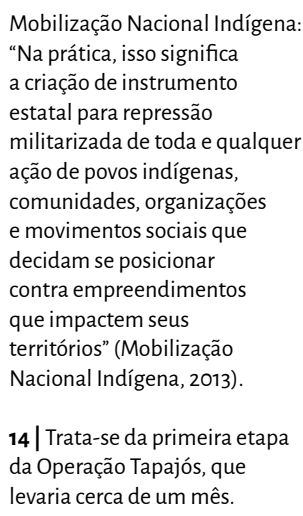


prévia que o poder público pretendia sobreimpor.

A situação é periclitante e o povo munduruku opta por uma medida drástica, a fim de conseguir chamar a atenção pública para os planos do governo na região do Tapajós, em meio à tanta violência e indiferença: qual seja, a ocupação do canteiro de obras de Belo Monte, em Vitória do Xingu.

Nós somos a gente que vive nos rios em que vocês querem construir barragens. Nós somos Munduruku, Juruna, Kayapó, Xipaya, Kuruaya, Asurini, Parakanã, Arara, pescadores e ribeirinhos. Nós somos da Amazônia e queremos ela em pé. Nós somos brasileiros. O rio é nosso supermercado. Nossos antepassados são mais antigos que Jesus Cristo.

Vocês estão apontando armas na nossa cabeça. Vocês sitiam nossos territórios com soldados e caminhões de guerra. Vocês fazem o peixe desaparecer. Vocês roubam os ossos dos antigos que estão enterrados na nossa terra.

Vocês fazem isso porque têm medo de nos ouvir. De ouvir que não queremos barragem. De entender por que não queremos barragem.

Vocês inventam que nós somos violentos e que nós queremos guerra. Quem mata nossos parentes? Quantos brancos morreram e quantos indígenas morreram? Quem nos mata são vocês, rápido ou aos poucos. Nós estamos morrendo e cada barragem mata mais. E quando tentamos falar vocês trazem tanques, helicópteros, soldados, metralhadoras e armas de choque.

O que nós queremos é simples: vocês precisam regulamentar a lei que regula a consulta prévia aos povos indígenas. Enquanto isso, vocês precisam parar todas as obras e estudos e as operações policiais nos rios Xingu, Tapajós e Teles Pires. E então vocês precisam nos consultar. Nós queremos dialogar, mas vocês não estão deixando a gente falar. Por isso nós ocupamos o seu canteiro de obras. Vocês precisam parar tudo e simplesmente nos ouvir. (Povo Munduruku, 2013d)

É de enorme força simbólica a ocupação do canteiro de obras do tão controverso e violentamente sobreimposto megacomplexo de Belo Monte, planejado para ser a terceira maior hidrelétrica do mundo. Naquele momento - maio de 2013 - a construção já se encontrava em seu ápice, mobilizando nada mais, nada menos que 25 mil trabalhadorxs, 24 horas por dia (cf. Almeida et al., 2013). "Belo Monte não pode parar?"

A ocupação de Belo Monte - que durou um total de 17 dias e contou com a participação direta de 170 indígenas, em sua maioria Munduruku -, literalmente interrrompe, com a introdução da temporalidade própria da ocupação, o suposto inexorável movimento do progresso/desenvolvimento, revelando-o, em seu próprio cerne, como ele mesmo se apresenta: um verdadeiro "deserto de buracos e concreto", tal qual uma violenta distopia devastadora de espaços que torna a vida impossível. 
Não queríamos estar de volta no seu deserto de buracos e concreto. Não temos nenhum prazer em sair das nossas casas nas nossas terras e pendurar redes nos seus prédios. Mas, como não vir? Se não viermos, nós vamos perder nossa terra. Nós queremos a suspensão dos estudos e da construção das barragens que inundam os nossos territórios, que cortam a floresta no meio, que matam os peixes e espantam os animais, que abrem o rio e a terra para a mineração devoradora. Que trazem mais empresas, mais madeireiros, mais conflitos, mais prostituição, mais drogas, mais doenças, mais violência. (Povo Munduruku, 2013f)

A ocupação de Belo Monte, dia a dia, vai ganhando enorme repercussão, nacional e internacional. A série de cartas abertas publicizadas durante a ocupação veio, inclusive, a ser traduzida e com-partilhada em vários idiomas ${ }^{15}$. $\mathrm{O}$ governo procura, num primeiro momento, criminalizar a ocupação, recusando-se a dialogar com o povo munduruku: a Secretaria-Geral da Presidência da República chega a emitir uma nota detalhada acerca do caso, em que negava a "representatividade" dxs ocupantes, como "pretensas" ou "autodenominadas lideranças", a ponto de alegar que umx dxs "porta-vozes" munduruku seria "proprietário de seis balsas de garimpo ilegal", de modo a tentar caracterizar o movimento de ocupação como mero grupo sectário atuando em prol de interesses pessoais na região do Tapajós (SecretariaCeral da Presidência da República, 2013).

O governo perdeu o juízo. Gilberto Carvalho está mentindo. O governo está completamente desesperado. Não sabe o que fazer com a gente. Os bandidos, os violadores, os manipuladores, os insinceros e desonestos são vocês. E, ainda assim, nós permanecemos calmos e pacíficos. Vocês não. Vocês proibiram jornalistas e advogados de entrar no canteiro, e até deputados do seu próprio partido. Vocês mandaram a Força Nacional dizer que o governo não irá dialogar com a gente. Mandaram gente pedindo listas de pedidos. Vocês militarizaram a área da ocupação, revistam as pessoas que passam e vêm, a nossa comida, tiram fotos, intimidam e dão ordens.

Entendemos que é mais fácil nos chamar de bandidos, nos tratar como bandidos. Assim o discurso do Gilberto Carvalho pode fazer algum sentido. Mas nós não somos bandidos e vocês vão ter que lidar com isso (...) Hoje fazem seis meses que vocês assassinaram Adenilson Munduruku. Nós sabemos bem como vocês agem quando querem alguma coisa.

A má-fé é do Gilberto Carvalho. E, apesar de tudo, nós queremos que ele venha no canteiro dialogar conosco. Estamos esperando por você, Gilberto. Pare de mandar policiais com armas na mão para entregar propostas vazias. Pare de tentar nos humilhar na imprensa.

Nós estamos em seu canteiro e não iremos sair enquanto vocês não saírem das nossas aldeias. (Povo Munduruku, 2013e)
15| Como também sugere Molina (2017:18), acredito que ainda está para ser realizada uma análise compreensiva sobre a relação entre o que por vezes é chamado de "primavera" indígena e os protestos de junho de 2013 Uma série de ações diretas de (r)existência indígena, que passaram a ganhar ampla atenção pública, antecedem junho de 2013: a ocupação de Belo Monte pelo povo munduruku é uma delas. Outros dois exemplos marcantes são a intensificação, no mesmo período, das retomadas de terras tupinambá na Serra do Padeiro (BA) e seus desdobramentos (cf. Alarcon, 2014), bem como as significativas mobilizações desencadeadas, a partir do final de 2012, com a publicização da emblemática carta dos habitantes de tekoha Pyelito Kwe/Mbarakay — que, sob a iminência de expulsão

de suas terras por reintegração de posse, pedem à Justiça que seja então decretada sua

"morte coletiva", expondo a dramaticidade da situação enfrentada pelxs GuaraniKaiowá no Mato Grosso do Sul (Povo Guarani-Kaiowá de Pyelito Kue/Mbarakay, 2012). Vale lembrar que a própria carta aberta redigida pelo Movimento Passe Livre (MPL) no auge das manifestações de junho de 2013, endereçada à então presidenta Dilma Rousseff, não apenas menciona expressamente a luta dxs Munduruku e Guarani-Kaiowá, como também, a meu ver, é inspirada, em termos de forma e conteúdo, nas próprias cartas publicizadas pelos povos indígenas do Brasil e da América Latina, como os comunicados dos povos zapatistas (Movimento Passe Livre, 2013). Com isso, creio ser possível ao menos indicar, como fator relevante para a compreensão das manifestações de junho de 2013, a amplitude que as mobilizações indígenas alcançaram no período e seus desdobramentos - entre eles, o crescimento do apoio e do envolvimento ativo de diversos movimentos sociais autônomos com as lutas indígenas. 
A despeito das tentativas de criminalização do governo, a pressão nacional e internacional em favor dxs ocupantes segue crescendo. Cartas e manifestações de solidariedade e apoio à ocupação vão assomando: tanto da parte de povos indígenas (cf. Articulação dos Povos Indígenas do Brasil, 2013; Povo Ka'apor, 2013; Povo Mebêngôkre, 2013), quanto da parte de uma série movimentos e apoiadorxs da sociedade ${ }^{16}$. É particularmente marcante a carta que o povo beiradeiro de Montanha e Mangabal redige ao povo munduruku nesse momento, consolidando o que veio a se configurar uma tão significativa aliança em defesa de seus territórios e da floresta no Médio Tapajós:

\footnotetext{
Nunca tivemos muito contato com nossos vizinhos Munduruku, mas agora enfrentamos o mesmo inimigo e queremos nos unir à luta que eles já começaram. Achamos louvável o que eles estão fazendo, apoiamos as ações que eles estão tomando contra o modo como o governo federal está impondo as barragens no nosso rio. Nunca fomos consultados a respeito e exigimos que nos ouçam.

Damos todo apoio aos Munduruku que estão ocupando o canteiro de Belo Monte. Queremos que eles saibam que o que eles falam também representa nossas exigências. Queremos que os Munduruku saibam que eles falam também por nossa comunidade. Contem com a gente, queremos lutar unidos com vocês. (Associação de Moradores das Comunidades de Montanha e Mangabal, 2013)
}

Com todo o apoio, caem por terra os intentos de se colocar em questão a legitimidade $d x$ s ocupantes - estratégia discursiva que visa a ignorar a própria possibilidade de autodeterminação indígena e, consequentemente, de (r)existência indígena. O governo, ao atribuir a si mesmo a prerrogativa de dizer quem é ou não indígena (cf. Articulação dos Povos Indígenas do Brasil, 2013), procurou atuar a fim de restringir o embate no campo discursivo a termos de ordem exclusivamente ontológica, no sentido de "capturar" a suposta legitimidade do serindígena num suposto "passado" que nada teria de ver com o "presente". Desse modo, a (r)existência indígena só poderia emergir, no plano discursivo, necessariamente como má-fé: afinal, se não há indígenas legítimxs no "presente", então as reivindicações dxs ocupantes só podem ser autointeressadas (e o poder público, no caso, seria a vítima dessxs supostxs "aproveitadorxs").

No entanto, é interessante notar como as cartas da ocupação Belo Monte não respondem nos mesmos termos: não se busca, propriamente, comprovar a legitimidade dxs ocupantes. "Nós somos nós e o governo precisa lidar com isso" (Povo Munduruku, 2013f), limitam-se a responder. A afirmação do "nós" evoca, desde o primeiro enunciado da ocupação, e justamente a partir da situalidade $e^{17}$ dos povos da floresta (e munduruku, em particular), uma pluralidade de vozes: "[n]ós somos a gente que vive nos rios em que vocês querem construir barragens" (Povo Munduruku, 2013d, grifos meus). A situalidade própria que instaura a ocupação abre-se como um
16 | Boa parte das manifestações de apoio e solidariedade encontra-se compilada em: <https:// ocupacaobelomonte. wordpress.com/category/ cartas-de-apoio/s. $\mathbf{1 7} \mid$ Neste artigo, utilizo o termo situalidade para expressar, de acordo com o arcabouço das epistemologias feministas e antirracistas, que todo conhecimento e modo de ação é sempre situado, localizado. 
convite à participação, que acolhe múltiplos rios e suas gentes, bem como o "ser brasileiro", a "floresta" e toda a "ancestralidade", tal qual também vêm a ser evocados nas cartas. Trata-se de um "nós" que abre margem a uma dimensão plural e aberta, capaz de fazer con-fluir, no espaço-tempo da ocupação, múltiplas frentes de (r)existência, tal qual um encontro de águas. Não é à toa que segue crescendo o número de adesões e manifestações públicas de apoio e solidariedade axs ocupantes, ampliando exponencialmente a dimensão com-partilhada do fazer con-junto de (r)existências que, como rios, entrecruzam-se e crescem no espaço-tempo aberto pela ocupação: "essa é uma luta grande e de todos" (Povo Munduruku, 2013g).

\begin{abstract}
Não é possível que todos vocês vão continuar repetindo que nós indígenas fomos consultados. Todo mundo sabe que isso não é verdade. A partir de agora o governo tem que parar de dizer mentiras em notas e entrevistas. E de nos tratar como crianças, ingênuas, tuteladas, irresponsáveis e manipuladas. Nós somos nós e o governo precisa lidar com isso. E não minta para a imprensa que estamos brigando com os trabalhadores: eles são solidários à nossa causa! Nós escrevemos uma carta para eles ontem! Aqui no canteiro nós jogamos bola juntos todos os dias. Quando saímos da outra vez, uma trabalhadora a quem demos muitos colares e pulseiras nos disse: "eu vou sentir saudades".
\end{abstract}

Nós temos o apoio de muitos parentes nessa luta. Temos o apoio dos indígenas de todo o Xingu. Temos o apoio dos Kayapó. Nós temos o apoio dos Tupinambá. Dos Guajajara. Dos Apinajé, dos Xerente, dos Krahô, Tapuia, Karajá-Xambioá, Krahô-Kanela, Avá-Canoero, Javaé, Kanela do Tocantins e Guarani. E a lista está crescendo. Temos o apoio de toda a sociedade nacional e internacional e isso também incomoda bastante vocês, que estão sozinhos com seus financiadores de campanha e empresas interessadas em crateras e dinheiro. Nós ocupamos de novo o seu canteiro - e quantas vezes será preciso fazer isso até que a sua própria lei seja cumprida? (Povo Munduruku, 2013f)

As cartas a todo o momento indicam: não é o "lugar de fala" que se encontra ausente, ou que seria impossível, mas sim o "lugar de escuta". É como se dissessem que estão falando há muito tempo, e que há uma recusa em escutar, quando não silenciamento. Será que, ao interromper o ruído ensurdecedor do progresso/desenvolvimento do canteiro de obras que, quase como um fim em si mesmo, parece já "não poder parar", seria possível, então, abrir esse "lugar de escuta", ocupando justamente o ponto nevrálgico da destruição com a oportunidade de se fazer diferente? "Ainda que vocês não estejam dispostos a aprender ouvir, nós estamos dispostos a ensinar" (Povo Munduruku, 2013g).

Diante desse quadro, o governo se vê, então, forçado a não mais ignorar o apelo de diálogo. Xs ocupantes só deixam o canteiro de obras a fim de serem imediatamente transportados à Brasília, em um avião da Força Aérea Brasileira (FAB), rumo a um encontro presencial com o próprio Gilberto Carvalho. 
Nós não viemos negociar com vocês, porque não se negocia nem território nem vida. Nós somos contra a construção de barragens que matam a terra indígena, porque elas matam a cultura quando matam o peixe e afogam a terra. $E$ isso mata a gente sem precisar de arma. Vocês continuam matando muito. Vocês simplesmente matam muito. Vocês já mataram demais, faz 513 anos. (Povo Munduruku, 2013g)

A partir desse momento, a estratégia do poder público procura, não por acaso, inverter a equação, sugerindo que são xs ocupantxs - xs Munduruku — que têm se recusado sistematicamente ao diálogo. Isso porque a possibilidade de diálogo vem a ser colocada nos próprios termos que o governo quer sobreimpor: uma mera negociação de contrapartidas e compensações, uma vez que a consulta prévia, a seu ver, não seria deliberativa. Qualquer oportunidade de diálogo, nesses termos, é enquadrada como consentimento: que "suas propostas [as do povo munduruku] sejam incorporadas ao processo de tomada de decisão do governo no que diz respeito aos possíveis aproveitamentos hídricos da região" (Secretaria-Geral da Presidência da República, 2013, grifos meus). Daí a insistência dxs Munduruku em ter de constantemente afirmar que dialogar não é o mesmo que negociar ou concordar com as barragens, que não estão propondo "listas de pedidos", mas sim reiterando a forma própria como desejam ser consultadxs.

Reunimos com o ministro Gilberto Carvalho no dia em que chegamos. Ele nos chamou de mentirosos (em outras palavras), se recusou a assinar o recebimento dos nossos documentos, disse que não somos nós que escrevemos nossas cartas.

Quando a reunião acabou, Gilberto Carvalho disse no Jornal Nacional: "ouvimos longamente a fala [de nós, indígenas], as críticas, mas fomos absolutamente claros com eles, dizendo que o governo não vai abrir mão de seus projetos". Então, entendemos o recado do governo.

Dois dias depois, Paulo Maldos deu entrevista à Rádio Nacional da Amazônia: "consulta não é sim ou não". Também entendemos esse recado. Entendemos que o governo está dizendo: "nós vamos construir as hidrelétricas nas terras de vocês, não importa o que vocês digam. E mesmo que vocês sejam consultados, nós não vamos considerar a opinião de vocês." (Povo Munduruku, 2013h)

O que tais considerações dxs Munduruku revelam é que a prerrogativa de consulta livre, prévia e informada atrelada ao cumprimento da Convenção 169, mesmo sendo tida como o principal instrumento legal para assegurar que os povos indígenas tenham controle sobre intervenções planejadas pelo Estado em seus territórios, pode vir, também, a colocar os povos da floresta em uma situação difícil de lidar: ao não explicitar com clareza o poder de veto por parte das populações potencialmente afetadas como condicionante para a realização de um processo consultivo prévio ${ }^{18}$, a Convenção 169 abre margem a que as instâncias de diálogo acabem servindo
18 | A investigação especial sobre a Convenção 169 realizada por Renata Bessi (2017) - ao constatar que, na aplicação do mecanismo de consulta prévia em diversas localidades da América Latina, os governos sistematicamente se recusam a respeitar resultados que não Ihes são favoráveis - sugere que a Convenção poderia ser entendida como uma "tecnologia de dominação", pois, estando a maioria dos "recursos" hoje disponíveis em "terras tradicionalmente ocupadas", a prerrogativa de consulta emergiria como "uma tentativa de apaziguar a alta intensidade dos conflitos gerados pela entrada massiva de projetos de desenvolvimento em toda a região" (tradução minha). A reportagem também indica que a persistência das comunidades em se auto-organizarem a partir de seus próprios termos foi fundamental nos casos em que se logrou fazer (r)existência frente aos megaprojetos - como, acredito, também tem sido o caso dos povos munduruku e beiradeiro no Médio Tapajós. 
justamente para referendar aquilo a que os povos indígenas se opõem.

Da maneira análoga, a ação de recusa dos povos da floresta ao diálogo, uma vez identificadas as intenções do governo de tomá-lo como sinal de consentimento, perde em muito seu potencial de denúncia da coerção que lhe é subjacente, visto que o poder público mostra-se, em termos discursivos, como se estivesse ex ante aberto não só ao diálogo propriamente dito, mas também à "construção participativa" de um protocolo de consulta prévia: desse modo, o enfoque no caráter supostamente procedimental da constituição de processos consultivos "esvazia" as acusações substantivas de coerção, de maneira que o ônus termina por recair primordialmente sobre quem se recusa à participação nesse processo, correndo o risco de já não poder mais exercer qualquer influência sobre os acontecimentos.

Em meio a esse "fogo cruzado" - em que dialogar ou não dialogar passam a ser o mesmo que consentir com a própria opressão - os povos indígenas e ribeirinhos não podem simplesmente negar-se ao diálogo, nem contar exclusivamente com a "lei" para fazer valer suas demandas. Com efeito, o caminho encontrado a fim de mover a (r)existência, mesmo em meio a condições e correlação de forças tão adversas, foi a opção dos povos munduruku e beiradeiro em partir de uma perspectiva (pro) positiva, embasada em seus modos de organização sociopolítica: a elaboração de um protocolo próprio de consulta (Povo Munduruku, 2015a).

\section{O PROTOCOLO DE CONSULTA MUNDURUKU}

Ao criar cole(a)tivamente um documento propondo, em seus próprios termos, como requerem ser consultados - de modo a finalmente condicionar, assim, a consulta prévia ao poder de veto em cole(a)tivo - , os povos munduruku e beiradeiro acabam por conceber um fato jurídico, que não apenas consegue expor a lógica de progresso/desenvolvimento inerente à intencionalidade coercitiva do próprio caráter procedimental de um mecanismo de consulta supostamente participativo, como também adentra, de forma (pro)positiva, o campo de disputa interpretativa sobre a Convenção 169, de modo a fazê-la estrategicamente funcionar a seu favor.

O Protocolo de Consulta Munduruku (Povo Munduruku, 2015a), fundamentalmente, atua no sentido de vincular forma e conteúdo. Em outras palavras, o protocolo indica que a forma como se faz a consulta é tão relevante quanto o conteúdo mesmo que dela emana. Desse modo, uma consulta prévia só encontra validade se for realizada nos próprios termos dos povos munduruku e beiradeiro ${ }^{19}$ - de acordo com suas espacialidades e temporalidades próprias:

Todas as reuniões devem ser em nosso território — na aldeia que nós escolhermos —, e não na cidade, nem mesmo em Jacareacanga ou Itaituba. As reuniões não podem ser realizadas em datas que atrapalhem as atividades da comunidade (por exemplo, no tempo
19| O povo beiradeiro participou ativamente da construção do Protocolo de Consulta Munduruku. Como a Convenção 169 é relativa, a princípio, especificamente aos povos indígenas, a redação do protocolo se dá nos termos da autodeterminação do povo munduruku, fazendo referência à necessidade de ampliar a abrangência da convenção, de modo a igualmente considerar o povo ribeirinho no que se refere à consulta pública em seus próprios termos: "exigimos que as comunidades ribeirinhas que serão atingidas pelas barragens no rio Tapajós (como Montanha e Mangabal, Pimental e São Luiz) tenham seu direito à consulta garantido, de modo adequado e específico à realidade delas. Assim como nós, os ribeirinhos também têm o direito a uma consulta própria" (Povo Munduruku, 2015a). 
da roça, na broca e no plantio; no tempo da extração da castanha; no tempo da farinha; nas nossas festas; no Dia do Índio) (...) As reuniões devem ser na língua Munduruku e nós escolheremos quem serão os tradutores. Nessas reuniões, nossos saberes devem ser levados em consideração, no mesmo nível que o conhecimento dos pariwat (não índios). Porque nós é que sabemos dos rios, da floresta, dos peixes e da terra. Nós é que coordenaremos as reuniões, não o governo. (Povo Munduruku, 2015a)

Observações como essas apontam, implicitamente, que a forma com que o poder público procurou sobreimpor o processo de consulta - com celeridade, nos moldes "ocidentais" e desconsiderando o conhecimento dos próprios povos afetados - é, sob o ponto de vista munduruku e ribeirinho, uma violência. De modo (pro) positivo, o protocolo desfaz qualquer possibilidade de alegação de suposta neutralidade que poderia vir a ser invocada pelo Estado na discussão acerca dos termos procedimentais de um processo participativo.

Além disso, o protocolo reforça que "existe só um povo munduruku", de maneira que "as decisões do povo munduruku são coletivas". Com isso, procura-se evitar que processos consultivos sejam realizados unilateralmente, por meio de alguma associação munduruku ou de "lideranças" em separado (Povo Munduruku, 2015a) - o que impede, assim, que a mera disposição de diálogo possa vir a ser tomada como consentimento:

Os Munduruku de todas as aldeias — do Alto, Médio e Baixo Tapajós — devem ser consultados, inclusive daquelas localizadas em terras indígenas ainda não demarcadas. Nós não queremos que o governo nos considere divididos: existe só um povo Munduruku. Devem ser consultados os sábios antigos, os pajés, os senhores que sabem contar história, que sabem medicinas tradicionais, raiz, folha, aqueles senhores que sabem os lugares sagrados.

Os caciques (capitães), guerreiros, guerreiras e as lideranças também devem ser consultados. São os caciques que se articulam e passam informações para todas as aldeias. São eles que reúnem todo mundo para discutirmos o que vamos fazer. Os guerreiros e guerreiras ajudam o cacique, andam com ele e protegem o nosso território. As lideranças são os professores e os agentes de saúde, que trabalham com toda a comunidade.

Também devem ser consultadas as mulheres, para dividirem sua experiência e suas informações. Há mulheres que são pajés, parteiras e artesãs. Elas cuidam da roça, dão ideias, preparam a comida, fazem remédios caseiros e têm muitos conhecimentos tradicionais.

Os estudantes universitários, pedagogos munduruku, estudantes do Ibaorebu, os jovens e crianças também devem ser consultados, pois eles são a geração do futuro. Muitos jovens têm acesso aos meios de comunicação, leem jornal, acessam internet, falam português, sabem a realidade e têm participação ativa na luta do nosso povo (...)

Hoje, nós habitamos cerca de 130 aldeias, no Alto, Médio e Baixo Tapajós. Mas lembramos que, por causa da organização social do nosso povo, novas aldeias podem surgir. (Povo Munduruku, 2015a) 
O Protocolo de Consulta Munduruku é um documento detalhado, que faz referência às precondições - de acordo com a unidade, a espacialidade e a temporalidade munduruku - tanto para o processo de consulta em si, quanto para a sua própria construção. Além disso, o protocolo requerer, de início, a demarcação da Terra Indígena Sawré Muybu como ato de "boa-fé" da parte do governo para iniciar o processo de consulta ${ }^{20}$, e termina afirmando expressamente: "Nós temos o poder de veto. Sawe!".

A construção desse documento chegou a contar com o apoio, entre outros, do Ministério Público Federal (MPF) e veio, inclusive, a ser impresso em formato de cartilha - tanto em português quanto em munduruku (Povo Munduruku, 2016) ${ }^{21}$. O protocolo de consulta, conforme aponto adiante, toma corpo de modo estreitamente vinculado ao processo de autodemarcação de Daje Kapap Eypi (Sawré Muybu). Realizados concomitantemente, tanto o protocolo de consulta quanto a autodemarcação do território munduruku ameaçado pelas barragens ganham força e consistência a partir da persistência dos povos munduruku e ribeirinho em sua própria autodeterminação. Dessa forma, ambas as ações vêm a contribuir decisivamente para alterar um quadro tão adverso - caracterizado por enormes disparidades em termos de correlação de forças — em favor dos povos da floresta, o que é evidenciado pelo real impedimento de efetivação do megaempreendimento hidrelétrico de São Luiz e Jatobá em suas terras.

\section{AUTODEMARCAÇÃO DE DAJE KAPAP EYPI}

Depois da ocupação do canteiro de obras de Belo Monte, intensificaram-se uma série de ações diretas dos povos munduruku e ribeirinho, que são de dupla ordem. Por um lado, trata-se de ações referentes a movimentos (pro)positivos que estão em acordo com sua própria lógica de autodeterminação sociopolítica - as quais conferem corpo à (r)existência, bem como às alianças que vão sendo constituídas (local ou mais amplamente) em prol de sua luta contra a sobreimposição das barragens. Por outro lado, os povos munduruku e beiradeiro também atuam estrategicamente no sentido de esgotar, de modo direto e (pro)positivo, todos os caminhos institucionais formais que se relacionam às suas lutas. Em somatória, esse modo de fazer con-junto, sustentado em ações (pro)positivas de dupla ordem, abre margem ao flor-e-s(c)er da (r)existência munduruku e ribeirinha, bem como ao desvelamento dos limites das normativas condicionadas exclusivamente ao âmbito institucional formal, de modo a evitar qualquer possibilidade de deslegitimação — quando não de criminalização — de seus movimentos próprios de autodeterminação sociopolítica.

Após os eventos em Brasília que sucederam a ocupação Belo Monte - entre os quais se incluem, também, um protesto em frente ao Ministério de Minas e Energia (MME) e a ocupação da Funai por três dias - , o povo munduruku, no final de junho de 2013, encontra, em seu território, biólogos funcionários do grupo
20| Tal exigência advém da morosidade na demarcação da Terra Indígena Sawré Muybu que, conforme aponto adiante, está especificamente relacionada aos entraves jurídicos que implicaria face ao licenciamento de construção da hidrelétrica de São Luiz, que a inundaria em grande parte.

21 | O Protocolo de Consulta Munduruku foi construído em uma série de reuniões conjuntas dos povos mundurukue ribeirinho no fim de setembro de 2014, sendo aprovado em assembleia geral munduruku em dezembro do mesmo ano. Em janeiro de 2015, o documento é formalmente entregue pelos povos munduruku e beiradeiro na Secretaria-Ceral da Presidência da República, em Brasília. 
Concremat, vinculado ao Grupo de Estudos Tapajós, formado por nove empresas interessadas na execução do empreendimento ${ }^{22}$, realizando estudos para a viabilização das barragens de São Luiz e Jatobá (cf. Santana, 2013c; Sposati, 2013). No total, três biólogos foram capturados e os materiais por eles coletados em território munduruku - amostras de fauna e flora - foram apreendidos: "Nós deixamos claro para o governo federal que não iríamos deixar entrar nenhum pesquisador nos nossos territórios" (Povo Munduruku, 2013i). Os biólogos foram libertos dois dias depois, assim que o governo federal comprometeu-se a suspender os estudos na área em que estão planejadas as hidrelétricas de São Luiz e Jatobá até a realização de consulta prévia.

A essa altura, o povo munduruku vinha enfrentando um contexto de crescente incitação à violência contra os povos indígenas, em especial nos centros urbanos de Itaituba e Jacareacanga, inclusive por parte do poder público local - que, naquele momento, encontrava-se majoritariamente afinado com o projeto de sobreimposição das barragens do governo federal na região, a ponto de tentar intervir diretamente, de diversas formas, para desmobilizar a (r)existência munduruku (cf. Comitê Metropolitano Xingu Vivo para Sempre et al., 2013; Santana, 2013a). Procurando evitar o acirramento da tensão que vinha colocando xs indígenas em situação de cada vez maior risco na região, o povo munduruku, ainda no mês de junho, ocupa a Câmara Municipal de Vereadores de Jacareacanga, a fim de interpelar publicamente xs vereadorxs favoráveis às hidrelétricas, bem como colocar em questão as inúmeras ameaças que vinha recebendo de sua parte (Conselho Indigenista Missionário, 2013). Também chegam a protestar diante da sede do Diálogo Tapajós ${ }^{23} \mathrm{em}$ Jacareacanga. Trata-se de um período de sucessivos embates e ações de (r)existência ${ }^{24}$ no contexto local.

Em meio a esses eventos, o governo rompe o acordo com xs Munduruku de suspensão dos estudos de licenciamento das hidrelétricas de São Luiz e Jatobá até que a consulta prévia fosse realizada. No dia 10 de agosto de 2013, uma espécie de reedição da Operação Tapajós é retomada na região, com a presença ostensiva da Força Nacional e de 130 técnicxs para a consecução dos estudos (cf. Santana, 2013b). Foi planejado pelo governo federal que essa nova operação seria conduzida na região em duas etapas, até o fim de novembro do mesmo ano. Ao clima de tensão já vivido em março, na primeira incursão da Operação Tapajós, é acrescida, naquele momento, a recente escalada de conflitos incitados pelo poder local. No início de setembro, parte das tropas e dxs técnicxs adentram a aldeia Boca, ameaçando o povo munduruku, caso tentassem impedir a realização dos estudos para a viabilização das hidrelétricas (Santana, 2013d). Dessa vez, a militarização da região por parte do governo termina chamando ainda maior atenção pública — diversos apoiadorxs e jornalistas seguem se somando, inclusive presencialmente, às articulações locais de (r)existência.
22 | De acordo com informações institucionais então disponíveis, o Grupo de Estudos Tapajós - formado pelas empresas Eletrobras, Eletronorte, GDF Suez, EDF, Neoenergia, Camargo Corrêa, Endesa Brasil, Cemig e Copel - foi criado a fim de realizar "estudos de viabilidade técnica-econômica" e "ambientais" que permitam cumprir as etapas necessárias para o licenciamento das hidrelétricas.

23| O Diálogo Tapajós, vinculado ao Grupo de Estudos Tapajós, apresentou-se, à época, como "um projeto de comunicação e interação social" visando a promover, durante a realização de "estudos de viabilidade dos Aproveitamentos Hidrelétricos São Luiz do Tapajós e Jatobá", "um processo dialógico e inclusivo de comunicação com as populações e instituições interessadas". Teve grande atuação na região de Jacareacanga e Itaituba, especialmente entre $2012 \mathrm{e}$ 2015, produzindo uma série de materiais impressos, vídeos e áudios (inclusive em língua munduruku) e promovendo inúmeros encontros, tanto com a população local quanto com o poder público, visando supostamente a 'esclarecer dúvidas' acerca do empreendimento hidrelétrico, dos direitos das populações e suas possíveis compensações — chegando, inclusive, a elaborar uma 'lista prévia' de cadastro socioeconômico, bastante completo e amplamente divulgado, das populações potencialmente atingidas pelas barragens.

24 | Não entrarei nos detalhes dos inúmeros embates enfrentados, nesse período, pela auto-organização do povo munduruku, desencadeados a partir de múltiplos e variados intentos de desmobilização da (r)existência e incitação de violência no contexto local. Indico apenas alguns fatores que ajudam a demonstrar a gravidade da situação enfrentada pelo povo munduruku. Já entre as ações de (r)existência, destaca-se a redação da Carta de Santarém, em que 26 entidades e movimentos declaram publicamente seu rechaço à construção de hidrelétricas no Tapajós, em agosto de 2013 (Santana, 2013c). 
Ganha ampla repercussão a controversa segunda audiência pública relativa à hidrelétrica de São Manuel ${ }^{25}$, promovida pelo Instituto Brasileiro do Meio Ambiente e dos Recursos Renováveis (Ibama) durante o período de vigência da nova operação militar - mais precisamente, em 29 de setembro - na cidade de Jacareacanga, deixando evidente o que implicaria, naquele momento, um processo de consulta prévia nos moldes sobreimpostos pelo governo (cf. Bradford, 2013; Fernández, 2014; Monteiro, 2013).

Na audiência, a presença policial foi ostensiva: "Parecia estado de sítio. Policiais militares e da força tática fortemente armados, agentes da prefeitura espalhados por todo o lugar, políticos e o próprio prefeito monitorando e esbravejando pelos cantos, proibindo e deixando de proibir", relata Claudemir Monteiro, coordenador do Conselho Indigenista Missionário (Cimi) Norte (Monteiro, 2013), presente no local. Ainda assim, o povo munduruku, em protesto, consegue barrar a entrada da audiência por cerca de uma hora.

Segundo relatos, além dxs participantes, a mídia — com exceção da TV Buré, afiliada aoSBT e sob influência do prefeito de Jacareacanga, bem como do Cimi-foi violentamente proibida de cobrir o evento, a ponto de arquivos fotográficos serem apagados à revelia e máquinas fotográficas confiscadas e quebradas. Muitxs indígenas, que haviam levado faixas com dizeres que expressavam indignação com relação aos projetos de construção de hidrelétricas na região do Tapajós, foram proibidxs de colocá-las no ginásio onde o evento foi realizado (Bradford, 2013; Fernández, 2014; Monteiro, 2013).

Além da forte presença policial, não houve qualquer estímulo à "participação" durante a suposta audiência pública. A apresentação, em vez de apontar os potenciais impactos da hidrelétrica às comunidades afetadas, limitou-se a "enaltecer" a construção da barragem como sinônimo de progresso e desenvolvimento, como se fosse desejável, lançando mão de um linguajar "técnico" (Bradford, 2013; Fernández, 2014). As perguntas, que tinham de ser entregues por escrito, ignorando a relevância da oralidade, tão cara aos povos da floresta, eram previamente selecionadas, de maneira que questionamentos críticos à barragem foram censurados. Nessa audiência, portanto, o povo munduruku pôde experienciar a gravidade e as implicações do caráter não performativo (Ahmed, 2012) de um processo de consulta pública concebido exclusivamente a partir da situalidade do poder público, em termos tanto de forma quanto de conteúdo - o que vem, posteriormente, a informar a construção de seu próprio protocolo de consulta.

Diante de tal quadro, várias assembleias do povo munduruku são convocadas no período, visando a articular possibilidades de (r)existência - entre elas uma assembleia geral, realizada na aldeia Restinga, com a presença de 65 caciques e mais de 400 indígenas, em novembro de 2013, e a $3^{\text {a }}$ assembleia do movimento Ipereg'ayu, em abril de 2014, para a qual o governo, que havia sido convidado a participar, não
25 | Essa audiência pública havia sido alvo de disputa entre diferentes instâncias do Estado: a suspensão de sua realização, movida por ação do Ministério Público Federal (MPF) devido à não conclusão do estudo do "componente indígena" - precondição para a identificação de potenciais impactos da hidrelétrica de São Manoel sobre as comunidades que viriam a ser consultadas foi revertida pela AdvocaciaCeral da União (ACU) praticamente às vésperas de sua realização (cf. Bradford, 2013). Outras audiências públicas similares são realizadas no mesmo período —uma delas, em Itaituba. 
comparece. Em termos de ações (pro)positivas de autodeterminação, também vem a ser auto-organizada uma grande inspeção, que envolveu várixs guerreirxs munduruku, com o objetivo de eliminar a operação de garimpo em seu território, em fevereiro de 2014 (Saud, 2014a).

É relevante mencionar que o povo munduruku, no primeiro semestre de 2014, teve ainda de mobilizar-se amplamente também por conta da arbitrária não renovação do contrato de 70 professorxs indígenas pela prefeitura, o que foi interpretado como represália devido a seu posicionamento contrário à construção das hidrelétricas. As crianças munduruku ficaram sem aulas no período. Visando a recontratação dxs professorxs, o povo munduruku realizou uma série de ações diretas em Jacareacanga, incluindo protestos e ocupações de órgãos públicos (Saud, 2014b). Com o clima já tenso de hostilização aos povos indígenas na cidade, em maio de 2014 um grupo de 20 munduruku é atacado por uma horda de cerca de 500 pessoas com paus, pedras e rojões - entre elas garimpeiros (que vinham ameaçando o povo munduruku desde sua ação contra o garimpo em seu território), comerciantes locais e membros do poder público da cidade, identificados como insufladores da ação-, o que resultou em dois indígenas gravemente feridxs (Movimento Xingu Vivo para Sempre, 2014). O Ministério Público é acionado no caso (Glass; Saud, 2014). Após múltiplos embates, o povo munduruku consegue, em julho de 2014, que xs professorxs sejam finalmente recontratadxs.

Ao mesmo tempo, seguem as ações diretas do povo munduruku sobre as instâncias formais do poder público também em âmbito federal. Atos são realizados em Brasília, como a ocupação, junto com outros povos indígenas atingidos por Belo Monte, da Advocacia-Ceral da União (ACU), em dezembro de 2013, visando a pressionar pela publicação do RCID da Terra Indígena Sawré Muybu - que, aliás, já se encontrava finalizado desde setembro, apenas aguardando a publicação pela Funai.

Embasado nesse duplo modo de ações diretas — relativas à sua autodeterminação e a fim de pressionar ao máximo o poder público — o povo munduruku tem como efeito, por um lado, revelar a situalidade do Estado na condução de suas normativas, que são manejadas em detrimento dos povos indígenas enquanto supostamente serviriam para garantir seus direitos, bem como, por outro lado, seguir legitimando suas próprias ações (pro) positivas de autodeterminação, inviabilizando as acusações de suposta "recusa" ao diálogo que lhe vinham sendo, até então, sistematicamente imputadas.

Nesse sentido, são especialmente marcantes os acontecimentos que envolvem a decisão do povo munduruku — em atuação con-junta com o povo ribeirinho — por autodemarcar seu próprio território ameaçado pelas barragens. Trata-se de uma ação (pro)positiva de autodeterminação em seus próprios termos que, além de fortalecera (r)existência munduruku e ribeirinha, ainda contribui para revelar, de forma patente, a má-fé inerente ao modus operandi das leis a partir da exposição de sua situalidade. 
No segundo semestre de 2014, o povo munduruku teve acesso ao RCID da Terra Indígena Sawré Muybu (Fundação Nacional do Índio, 2013) que o governo se recusava, sistematicamente, a publicar - passo necessário a fim de dar consecução ao processo legal de demarcação do território munduruku. Conforme visto, o povo munduruku, de longa data, procurava fazer pressão - por meio de ações diretas - pela publicação do relatório. Essa questão, inclusive, chegou a se desdobrar em uma série de disputas no plano jurídico entre diferentes instâncias do governo. Aos poucos, as ações do povo munduruku iam esgotando todas as formas de atuação possível dentro dos meandros institucionais - de modo que os esforços por pressionar diretamente o poder público, criando-lhe cada vez maiores constrangimentos, foram pouco a pouco permitindo desvelar, na própria linguagem institucional, as reais intenções do governo na não publicação do relatório. Com isso, as ações (pro) positivas de autodeterminação do povo munduruku, por sua vez, iam ganhando ampla legitimidade e corpo, de modo a desencadear uma configuração em campo que foi tornando praticamente impossível que se seguisse ignorando, juridicamente, a existência de Daje Kapap Eypi.

A recusa na publicação do relatório coincide com o momento em que o governo federal buscava, por todos os meios possíveis, acelerar o licenciamento de construção da hidrelétrica de São Luiz - que, justamente, inundaria a Terra Indígena Sawré Muybu, em processo de demarcação. A publicação do relatório, portanto, ao dar consecução ao processo de demarcação de Sawré Muybu, viria a impor um entrave jurídico muito maior ao licenciamento das barragens no Médio Tapajós, uma vez que a legislação acerca de intervenção estatal sobre territórios indígenas oficialmente reconhecidos é muito mais complexa - ainda mais por envolver, no caso específico, a necessidade de remoção de indígenas de seu próprio território. Assim, apesar de a Terra Indígena Sawré Muybu, naquele momento, já haver sido legalmente identificada — de acordo com a linguagem dos trâmites referentes à demarcação - , evitar sua formalização e demarcação torna-se uma estratégia para que, juridicamente, possa-se ignorar a presença indígena na região, facilitando o licenciamento do megaempreendimento hidrelétrico.

Em setembro de 2014, concomitante aos embates relacionados à publicação do relatório, os estudos relativos à construção da hidrelétrica de São Luiz haviam sido supostamente "concluídos". Assim, paralelamente, havia ampla movimentação nas instâncias institucionais formais pela a provação desses estudos. A pressa do governo pelo licenciamento da barragem de São Luiz era de tal ordem que, enquanto ainda estavam tramitando pareceres sobre a própria viabilidade da usina ${ }^{26}$, o MME chega a tentar autorizar a licitação da hidrelétrica ainda em $2014^{27}$.

Se, por um lado, o Estado procura ignorar — por meio da não publicação do relatório - a existência de território indígena na região, também busca, por outro lado, fingir consultar os povos indígenas potencialmente afetados pelas barragens no
$26 \mid$ Em 15 de agosto de 2014 a Funai opõe-se aos estudos realizados justamente por falta do "componente indígena" —ou seja, os estudos não apresentavam evidências de haver consultado nem ouvido os habitantes das aldeias indígenas afetadas. Em 12 de setembro, um novo estudo é apresentado, em que o "componente indígena" havia sido acrescentado, apenas com a recomendação de remoção de aldeias afetadas. Em 25 de setembro, um parecer interno da Funai declara insuficiência do "componente indígena" por falta de trabalho de campo, entre outros pontos apresentados.

27 Trata-se da portaria $n^{\circ}$ 485, de 12 de setembro de 2014, que estipulava a data do leilão em 15 de dezembro do mesmo ano. Com a ampla repercussão negativa gerada pela publicação dessa portaria, e por ação do Ministério Público, ela vem a ser revogada em 17 de setembro. No entanto o MME afirma pretender levar as hidrelétricas no Médio Tapajós à leilão ainda no primeiro semestre de 2015 
Tapajós: reuniões de proposta de consulta prévia na região são agendadas para o mês de outubro, na cidade de Itaituba — sem sequer haver sido realizado, de modo apropriado, o estudo do "componente indígena", que seria pré-requisito para a consulta pública. Diante disso, os principais encontros entre os povos munduruku e ribeirinho para a elaboração de seu protocolo de consulta ocorrem já no fim de setembro, justamente a fim de evitar novas edições de simulação de processos de consulta, tal qual visto no caso da audiência pública acerca da hidrelétrica de São Manoel ${ }^{28}$.

Em 17 de outubro, Maria Augusta Assirati, então presidenta interina da Funai, em emblemática reunião com o povo munduruku, ao ser questionada pela não publicação do relatório, com a qual havia se comprometido expressamente, termina por vir a revelar, verbalmente, que não iria assiná-lo nem publicá-lo, em meio àquela conjuntura, por conta dos interesses do governo na construção das hidrelétricas que viriam a atingir a Terra Indígena Sawré Muybu. Esse evento é filmado pelo povo munduruku (Povo Munduruku, 2014a) e ganha ampla repercussão pública. Nove dias depois, Assirati renuncia à presidência da Funai — sem, no entanto, publicar o relatório ${ }^{29}$. Em sequência a esse evento, os povos munduruku e ribeirinho, com o relatório da Terra Indígena Sawré Muybu não publicado em mãos, decidem não mais esperar pela Funai e iniciar, por si mesmos, o processo de autodemarcação do território.

Garantir o nosso território sempre vivo é o que nos dá força e coragem. Sem a terra não sabemos sobreviver. Ela é a nossa mãe, que respeitamos. Sabemos que contra nós vem o governo com seus grandes projetos para matar o nosso Rio, floresta, vida.

Esse território atende às populações do Médio e Alto Tapajós.

Esperamos pelo governo há décadas para demarcar nossa Terra e ele nunca o fez. Por causa disso é que a nossa terra está morrendo, nossa floresta está chorando, pelas árvores que encontramos deixadas por madeireiros nos ramais para serem vendidas de forma ilegal nas serrarias e nisso o Ibama não atua em sua fiscalização. Só em um ramal foi derrubado o equivalente a 30 caminhões com toras de madeiras, árvores centenárias como o Ipê, áreas imensas de açaizais são derrubadas para tirar palmitos. Nosso coração está triste.

Nesses 30 dias da autodemarcação já caminhamos cerca de $7 \mathrm{~km}$ e fizemos 2,5 km de picadas. Encontramos 11 madeireiros, 3 caminhões, 4 motos, 1 trator e inúmeras toras de madeiras de lei às margens dos ramais em nossas terras, e na manhã do dia 15 fomos surpreendidos em nosso acampamento por um grupo de 4 madeireiros, grileiros liderados pelo Vilmar que se diz dono de 6 lotes de terra dentro do nosso território, disse ainda que não irá permitir perder suas terras para nós e na segunda próxima estaria levando o caso para a justiça.

Agora decretamos que não vamos esperar mais pelo governo. Agora decidimos fazer a autodemarcação, nós queremos que o governo respeite o nosso trabalho, respeite nossos antepassados, respeite nossa cultura, respeite nossa vida. Só paramos quando concluir o nosso trabalho. SAWE, SAWE, SAWE. (Povo Munduruku, 2014C)
28 | Em novembro de 2014 o governo entra com o mecanismo de suspensão de segurança para dar início à construção da usina de São Manoel, a despeito do não cumprimento das prerrogativas legais para tanto.

29| O RCID da Terra Indígena Sawré Muybu veio a ser publicado apenas em 19 de abril de 2016 - justamente durante a "brecha" institucional aberta devido à ação de impeachment contra a então presidenta Dilma Rousseff, que se deu apenas alguns dias depois. 
A autodemarcação é uma ação (pro)positiva de autodeterminação que (in) diretamente denuncia, de forma patente, a própria ilegitimidade da norma - a qual se revela não apenas situada, favorecendo sobretudo interesses contrários aos do povo munduruku, mas também sinal de má-fé. Isso porque, ao referendar um modo de atuação embasado na discrepância entre o que se fala e o que se faz, a norma mostra-se conivente com as múltiplas violências sofridas pelos povos da floresta, naturalizando-as. A autodemarcação, contrariamente, faz coincidir o que se fala com 0 que se faz: "a nossa palavra deve ser sempre como um rio, que corre sempre na mesma direção" (Povo Munduruku, 2014d). Trata-se de palavras que são corpo e movimento, e de ações que, incorporadas, comunicam: palavrações. É nesse caráter indissociável entre o que se fala e o que se faz - entre forma e conteúdo - que se encontra a força e o sentido de uma ação con-junta como a autodemarcação de Daje Kapap Eypi. Ao con-fluir com(o) o rio, o processo de autodemarcação corrobora cole(a)tivamente para que todos os seres viventes, em con-junto com as águas do Tapajós, possam continuar seguindo livremente seu curso tão próprio, contra a barragem da norma. Com efeito, ao se configurar a partir de referentes próprios, a autodemarcação recoloca os termos do debate também no que tange o que se entende por território, como aponto no que segue. Ademais, o desencadeamento do processo de autodemarcação vem a conferir ampla legitimidade pública ao território e à luta munduruku e ribeirinha, consolidando a terra indígena, com todos os seres viventes que nela habitam e interagem com o entorno, como fato que não pode mais ser ignorado. Na condição de ato de espacialização de corpos territorializados, a autodemarcação, sobretudo, vem a fortalecer a (r)existência munduruku e beiradeira como um todo.

Onde há barragens, todo o entorno é afetado, potencializando a destruição que já se encontra em curso. A noção de território que a autodemarcação coloca, portanto, é de ordem fundamentalmente distinta daquela sobreimposta pela norma, indo muito além da delimitação de marcos fronteiriços. Enquanto os embates relativos à publicação do relatório entre a Funai e os demais órgãos do governo restringe-se exclusivamente a uma querela sobre ultrapassar ou não certos limites territoriais como se a terra fosse, meramente, um substrato material, fragmentável e sujeitável à lógica de a propriação — , a autodemarcação de Daje Kapap Eypi, realizada con-juntamente entre os povos munduruku e ribeirinho, evidencia que a relacionalidade estabelecida entre corpo e território é vida que, como tal, desconhece fronteiras: envolve o rio, a floresta e tudo o que neles co-move, em espacialização. Sempre plural, jamais estática ou fixável a supostos limites, a vida emerge em interação com todo o entorno. Não há corpos sem floresta e não há floresta sem corpos: é nessa imbricação que a vida encontra lugar e pode, à sua maneira, flor-e-s(c)er. Realizada a partir dos referentes próprios dos povos munduruku e ribeirinho, portanto, a autodemarcação coloca o debate em outros termos, que permitem a apreensão da complexidade envolvida nos movimentos con-juntos de espacialização que co-movem a floresta 
— os quais não se deixam imobilizar pela lógica do progresso/desenvolvimento, que reduz a terra e tudo o que nela se encontra a meros "recursos" a serem explorados.

Na primeira etapa da autodemarcação de Daje Kapap Eypi, que tem início em outubro de 2014, participam ao todo, contando as quatro expedições realizadas até o fim de fevereiro de 2015, cerca de 20 guerreirxs e beiradeirxs de Montanha e Mangabal, bem como alguns apoiadorxs e jornalistas. Munidxs de um aparelho GPS, a cada incursão foram autodemarcando, com placas e picadas abertas em meio à floresta, os "pontos" - limites físicos de Daje Kapap Eypi, tal qual indicados no próprio relatório da Funai.

Ao longo de seu transcurso, a autodemarcação vai ganhando corpo e assume crescente relevância no que concerne à autodeterminação sociopolítica dos povos munduruku e beiradeiro. Em meio a tantos embates enfrentados no período, a construção do protocolo de consulta e, em especial, a autodemarcação de Daje Kapap Eypi, na condição de movimentos (pro)positivos cole(a)tivos, fortalecem sua (r)existência localmente e a partir de seus próprios termos, vindo a ser fundamentais a fim de evitar recair em uma postura meramente reativa diante de todo o assédio vivido. As cartas da autodemarcação, redigidas durante o percurso, vão alcançando cada vez maior publicização (Povo Munduruku, 2014c; 2014d; 2014e). Começam, assim, a ser alterados os paradigmas do debate acerca dos sentidos atribuídos à terra indígena e suas implicações.

O processo de autodemarcação atinge grandes proporções. A segunda etapa, realizada em julho de 2015, envolvendo três grandes percursos, chegou a contar com a participação de mais de 60 pessoas: ao menos 40 guerreirxs do Alto Tapajós, provenientes de cerca de dez aldeias distintas, deslocaram-se para o Médio Tapajós a fim de participar da ação con-junta de autodemarcação com xs guerreirxs munduruku e beiradeirxs locais. Apoiadorxs e jornalistas também participaram da autodemarcação.

Ao longo de todo o trajeto, foram encontrados, em território munduruku, inúmeros ramais abertos por madeireiros, açaizais explorados por palmiteiros, acampamentos de garimpo, ativos e abandonados. Fortes sinais da destruição da floresta, em pleno território munduruku. Xs guerreirxs dão aviso a garimpeiros e madeireiros: essa terra não é de vocês. Situação delicada, que abriu margem para o aumento de inúmeras ameaças, tanto durante a autodemarcação quanto posteriormente.

A autodemarcação é, sem dúvidas, um acontecimento que envolve enorme risco: sem contar com qualquer amparo legal de proteção, os povos munduruku e beiradeiro se colocam em situação de ainda maior exposição a agressões, represálias e assassinatos, em um contexto de alta tensão e já tão marcado por inúmeros conflitos e feridas abertas. No entanto, como uma das cartas da autodemarcação afirma, "[s]em chorarou transformando lágrimas em coragem" (Povo Munduruku, 2014e), os povos munduruku e ribeirinho vêm também a retomar, com a autodemarcação, uma dimensão ampliada não só da destruição da floresta em seu território, mas também da força e da relevância de seu processo cole(a) tivo de (r)existência, fundamental para que sua sobrevivência possa seguir flor-e-s(c)endo. Nesse sentido, foi também incluído, no trajeto da demarcação, a passagem por Daje Kapap 
(Os Fechos), local sagrado para o povo munduruku, vinculado à passagem dos porcos e de Karosakaybu, de suma importância para sua história ${ }^{30}$ como povo.

Quando nós passamos onde os porcos passaram, eu tive uma visão deles passando. Eu tenho 30 anos. Quando eu era criança minha mãe me contou a história dos porcos. É por isso que devemos defender nossa mãe terra. As pessoas devem respeitar também. Todas as pessoas devem respeitar porque a história está viva, estamos aqui, somos nós.

(Orlando Borô Munduruku, aldeia Waro Apompu, Alto Tapajós)

Hoje, pela primeira vez durante a autodemarcação, chegamos ao local sagrado Daje Kapap Eypi, onde os porcos atravessam levando o filho do Guerreiro Karosakaybu. Sentimos algo muito poderoso que envolveu o nosso corpo.

Outra emoção forte que sentimos hoje foi ver nossa terra toda devastada pelo garimpo bem perto de onde os porcos passaram. Nosso santuário sagrado está sendo violado, destruído por 50 PCs (retroescavadeiras) em terra e 5 dragas no rio. Para cada escavadeira, 5 pobres homens, em um trabalho semiescravo, explorados de manhã até a noite por 4 donos estrangeiros. (Povo Munduruku, 2014e)

A autodemarcação, em si, vai muito além da mera denúncia do não cumprimento, por parte do governo federal, de suas próprias leis. Dentro das regras do jogo sobreimpostas pelo Estado, por mais (pro)positivamente que se atue, fica-se inevitavelmente refém de um entendimento restrito de território, como substrato material, que subjaz ao cerne da norma, uma vez que este é pressuposto para a instauração do poder de definir fronteiras, como se fosse possível dividir a floresta, "corta[r] a floresta no meio" (Povo Munduruku, 2013f). No lugar de repor essa lógica, os povos munduruku e ribeirinho, com a autodemarcação de Daje Kapap Eypi, passam a atuar a partir de outros termos, que lhes são próprios, no debate. Ou seja, além de apresentar, com as cartas da autodemarcação, a destruição em curso que está implicada em um território não demarcado - pressupondo, assim, a existência de Daje Kapap Eypi antes de qualquer demarcação oficial que pretende se colocar, ela mesma, como marco de origem - também levam os termos do debate a um paradigma distinto, expandindo a noção de territorialidade a partir de um movimento próprio de autodeterminação: não se está falando de meros limites territoriais, mas de um modo substantivo de vida em que corpo, floresta e rio encontram-se mutuamente imbricados, em co-movimento. A floresta, o rio e seus seres viventes - entre eles, os povos munduruku e beiradeiro - são um só. A floresta, que desconhece fronteiras, faz a vida fluir e flor-e-s(c)er, a partir de seu mistério tão próprio. É disso que, fundamentalmente, se trata a autodemarcação. Tanto que, ao fim da segunda etapa, depois que todos os "pontos" haviam sido percorridos, o cacique da aldeia Sawré Muybu (que se encontra em Daje Kapap Eypi) afirmou que
30| O historiador Jairo Saw Munduruku, enquanto me contava sobre a intrincada história da passagem dos porcos (a qual não ousarei tentar reproduzir aqui), fez questão de observar que não se trata de um mito, como xs brancxs diriam, mas sim de sua própria história como povo, tal qual acontece. Tive a oportunidade, em julho de 2015, de presenciar a história acontecer durante a apresentação do filme Daje Kapap Eypi (2015), de Lucivaldo Karo Munduruku e Eliano Kirixi Munduruku, na aldeia Praia do Índio (Itaituba): as conversas que se seguiram ao filme - que tratava, entre outros temas, da passagem dos porcos - incluíam variações e complementos possíveis da história, ali tão presente e tão viva. 
a autodemarcação, longe de ter terminado, havia tão somente começado: era apenas uma etapa que se havia cumprido. A partir de um entendimento substantivo de território como fazer cole(a)tivo e con-junto, abre-se, com a autodemarcação, a possibilidade de inima(r)gináveis movimentos de espacialização, capazes de co-mover a vida (r)existente, apesar de tudo.

IMAGINANDO

31 | As alterações gráficas de certos termos ao longo do texto, incluindo hifenizações,

A vida segue, assim, em aberto, como a própria flor-esta ${ }^{31}$

são intencionais.

Léa Tosold é ativista e pesquisadora. Possui mestrado em Letras, Filosofia e Ciência Política pela Universidade de Viena e em Filosofia Política pela Universidade de York. É doutora em Ciência Política pela Universidade de São Paulo, membro do Grupo Interdisciplinar de Estudos de Raça e Política (Gira), pesquisadora da Rede Nexos: Teoria Crítica e Pesquisa Interdisciplinar (UFABC) e do Grupo de Estudos em Teoria Política (Getepol/UEL). Atualmente, é Fellow do Maria Sibylla Merian Centre Conviviality-Inequality in Latin America (Mecila).

FINANCIAMENTO: Esta pesquisa foi parcialmente financiada pela Capes e conta, atualmente, com o apoio do Maria Sibylla Merian Centre Conviviality-Inequality in Latin America (Mecila).

CONTRIBUIÇÃO DE AUTORIA: Não se aplica.

\section{REFERÊNCIAS BIBLIOGRÁFICAS}

AHMED, Sara. 2012. On being included: racism and diversity in institutional life. Durham; Londres, Duke University Press.

ALARCON, Daniela Fernandes. 2014. "Retomadas de terra e ocupação militar: a disputa pela aldeia Tupinambá de Serra do Padeiro, Bahia”. 29a Reunião Brasileira de Antropologia. Disponível em http://www.29rba.abant.org.br/ resources/anais/1/1402018322_ARQUIVO_ RBA_Daniel a_Fernandes_Alarcon. pdf. Acesso em: 30 de maio de 2018.
BEN]AMIN, Walter. 2010 [1940]. Obras escolhidas: magia e técnica, arte e política. São Paulo, Brasiliense.

BENJAMIN, Walter. 2011 [1921]. "Para uma crítica da violência". In: BENJAMIN, Walter. Escritos sobre mito e linguagem (1915-1921). São Paulo, Livraria Duas Cidades; Ed. 34, pp. 121-156.

BUTLER, Judith. 1993. Bodies that matter: on the discursive limits of "sex". Nova York, Routledge. 
DAS, Veena. 1998. "Specificities: official narratives, rumour, and the social production of hate". Social Identities: Journal for the Study of Race, Nation and Culture, vol. 4, n. 1, pp. 109-130.

DAS, Veena. 2007. Life and words: violence and descent into the ordinary. Berkeley, University of California Press.

FEARNSIDE, Philip Martin. 2015 a. Hidrelétricas na Amazônia: impactos ambientais e sociais na tomada de decisões sobre grandes obras. Manaus, Ed. do Inpa.

FEARNSIDE, Philip Martin. 2015b. Impactos nas comunidades indígenas e tradicionais. In: NITTA, Renata; NAKA, Luciano N. (eds.), Barragens do rio Tapajós: uma avaliação crítica do Estudo e Relatório de Impacto Ambiental (EIA/Rima) do Aproveitamento Hidrelétrico São Luiz do Tapajós. São Paulo, Greenpeace Brasil, pp.19-29.

LOURES, Rosamaria Santana Paes. 2016. "Conflitos territoriais e grandes projetos na Amazônia brasileira: trajetória de luta do Movimento Munduruku Ipereğ Ayũ". V Congresso em Desenvolvimento Social: Estado, Meio Ambiente e Desenvolvimento, Montes Claros, MG. Disponível em http://www.congressods. com.br/anais/gt_08/CONFLITOS\%20 TERRITORIAIS\%20E\%20GRANDES\%20 PROJETOS\%2ONA\%2OAMAZONIA. pdf. Acesso em 20 de maio de 2017.

MATEBENI, Zethu. 2017. Perspectivas do Sul sobre relações de gênero e sexualidades: uma intervenção queer. Revista de Antropologia, v. 60, n. 3: 26-44. https://doi. org/10.11606/2179-0892.ra.2017.141826

MOLINA, Luísa Pontes. 2017. Terra, luta, vida: autodemarcações indígenase afirmação da diferença, dissertação de mestrado, Universidade de Brasília.
SEGATO, Rita Laura. 2016. "La norma y el sexo: frente estatal, patriarcado, desposesión, colonialidad". In BIDASECA, Karina (coord.), Genealogías críticas de la colonialidad en América Latina, África, Oriente. Buenos Aires, Idaes, pp. 31-64.

TOSOLD, Léa. 2018. Autodeterminação em três movimentos: a politização de diferenças sob a perspectiva da (des)naturalização da violência. São Paulo, tese de doutorado, Universidade de São Paulo.

\section{MATERIAIS CONSULTADOS}

AGÊNCIA ESTADO. 2012. "Greve paralisa (de novo) obra de Belo Monte". Gazeta do Povo, 23 abr. Disponível em http://www.gazetadopovo. com.br/economia/greve-paralisa-de-novo-obrade-belo-monte-1vpnndev40peo2940ibac6r7y. Acesso em 15 de outubro de 2015.

ALMEIDA, Lalo de; AMORA, Dimmi; KACHANI, Morris; LEITE, Marcelo; MACHADO, Rodrigo. 2013. "Tudo sobre a batalha de Belo Monte". Folha de S.Paulo, 16 dez. Disponível em http:// arte.folha.uol.com.br/especiais/2013/12/16/ belo-monte/. Acesso em 20 de maio de 2014.

ARANHA, Ana; MOTA, Jessica. 2014. "A batalha pela fronteira munduruku". A Pública: Agência de Jornalismo Investigativo, $11 \mathrm{dez}$. Disponível em http://apublica.org/2014/12/ batalha-pela-fronteira-munduruku/. Acesso em 20 de janeiro de 2017.

\section{ARTICULAÇÃO DOS POVOS INDÍCENAS DO BRASIL (APIB). 2013. "Manifesto} contra o preconceito institucionalizado do governo Dilma aos povos indígenas". Blog Ocupação Belo Monte, 7 mai. Disponível em https://ocupacaobelomonte.wordpress. com/2013/05/08/apib-manifesto-contrao-preconceito-institucionalizado-dogoverno-dilma-aos-povos-indigenas/. Acesso em 20 de junho de 2013. 


\section{ASSOCIAÇÃO DE MORADORES DAS COMUNIDADES DE MONTANHAE MANCABAL. 2013. "Carta de apoio aos Munduruku que ocupam Belo Monte", 28 mai. Disponível em https:// ocupacaobelomonte.wordpress.com. Acesso em 30 de maio de 2013.}

BARROS, Carlos Juliano. 2012. "A discórdia do desenvolvimento”. A Pública: Agência de Jornalismo Investigativo, 13 dez. Disponível em: http://apublica. org/2012/12/discordia-desenvolvimento/. Acesso em 05 de julho de 2013.

BESSI, Renata. 2017. "Consulta indígena legaliza despojo de los pueblos: Convenio 169 de la OIT". Avispa Midia, 12 jun. Disponível em https://avispa. org/consulta_indigena/index.html. Acesso em 20 de julho de 2017.

BRADFORD, Sue. 2013. "Jacareacanga: com intimidação de guerreiros munduruku, Ibama promove audiência pública da UH de São Manoel". Língua Ferina, 30 set. Disponível em http:// candidoneto.blogspot.com.br/2013/09/ jacareacanga-sob-intimidacao-de. html. Acesso em 02 de junho de 2018.

BRUM, Eliane. 2014. "Belo Monte: a anatomia de um etnocídio. Entrevista com Thaís Santi, procuradora da República em Altamira". El País, dez. Disponível em https://brasil.elpais.com/brasil/2014/12/01/ opinion/1417437633_930086.html.

Acesso em 02 de dezembro de 2014.

CARELLI, Vincent. 2017. Martírio. Documentário, longa-metragem.

CASTRO, Miguel Viveiros de. 2015. Mundurukânia: na beira da história. Documentário, 45m24s.
COMISSÃO PASTORAL DA TERRA (CPT). 2017. Conflitos no campo: Brasil 2016. São Paulo, Editora Expressão Popular.

COMITÊ METROPOLITANO XINGU VIVO PARA SEMPRE; FÓRUM DA AMAZÔNIA ORIENTAL (FAOR); REDE BRASIL SOBRE INSTITUIÇÕES FINANCEIRAS MULTILATERAIS. 2013. "Nota de repúdio à truculência na reunião com os Munduruku em Jacareacanga". Portal Combate Racismo Ambiental. Disponível em http://racismoambiental. net.br. Acesso em 17 de agosto de 2013.

\section{CONSELHO INDIGENISTA MISSIONÁRIO} (CIMI). 2013. "Munduruku protestam contra parlamentares que defendem construção de hidrelétricas". Portal Cimi, 24 jun. Disponível em https://www.cimi.org.br/2013/06/34982/. Acesso em 10 de agosto de 2013.

\section{CONSELHO INDIGENISTA MISSIONÁRIO}

(CIMI). 2014. Relatório violência contra povos indígenas no Brasil: dados de 2014. Brasília, Cimi.

CRIBARI, Isabela. 2014. De profundis. Documentário, 21m. Disponível em: https://vimeo.com/158411290. Acesso em 10 de janeiro de 2017.

CUNHA, Cândido Neto da. 2013. "Operação Tapajós: Coverno Federal entra em contradição sobre o envio de tropas e intenções de pesquisa". Língua Ferina, 31 mar. Disponível em http://candidoneto.blogspot.com.br/2013/03/ operacao-tapajos-governo-federal-entra_31. html. Acesso em 20 de janeiro de 2017.

ELKAIM, Aaron Vincent; NOLEN, Stephanie. 2017. "Os esquecidos: por dentro da crise de suicídios indígenas no Brasil". The Clobe and Mail, 17 mar. Disponível em https:// www.theglobeandmail.com/news/world/ os-esquecidos-por-dentro-da-crise-desuicidios-indigenas-no-brasil/article34321173/. Acesso em 20 de novembro de 2017. 
FELLET, João. 2014. "Dilma deixou a desejar no diálogo com a comunidade, diz ministro". BBC, 10 nov. Disponível em http://www.bbc. co.uk/portuguese/noticias/2014/11/141108_ entrevista_gilberto_jf_fd. Acesso em 20 de novembro de 2014.

FERNÁNDEZ, Nayana. 2014. Índios Munduruku: tecendo a resistência.

Documentário, 25m.

\section{FUNDAÇÃO NACIONAL DO ÍNDIO}

(FUNAI). 2013. Relatório Circunstanciado de Identificação e Delimitação da Terra Indigena Sawré Muybu (Pimental)/ PA. Brasília, set. Mimeografado.

GLASS, Verena; SAUD, Larissa. 2014. "MPF exigirá recontratação de professores Munduruku no Pará". Movimento Xingu Vivo para Sempre, 22 mai. Disponível em http://www.xinguvivo.org.br/2014/05/22/ mpf-exigira-recontratacao-deprofessores-mundurku-no-para/. Acesso em 23 de maio de 2014.

\section{INSTITUTO BRASILEIRO DO MEIO} AMBIENTE (IBAMA). 2014. "Terras indígenas apresentam o menor índice de desmatamento na Amazônia Legal". Funai, 23 jul. Disponível em http://www.funai.gov. br/index.php/comunicacao/noticias/2914terras-indigenas-apresentam-o-menorindice-de-desmatamento-na-amazonialegal. Acesso em 20 de julho de 2015.

INSTITUTO SOCIOAMBIENTAL. 2016. “O que o governo Dilma fez (e não fez) para garantir o direito à terra e áreas para conservação?”. Portal Instituto Socioambiental, 1 jun. Disponível em https://www.socioambiental.org/pt-br/ noticias-socioambientais/o-que-o-governodilma-fez-e-nao-fez-para-garantir-odireito-a-terra-e-areas-para-conservacao. Acesso em 10 de julho de 2016.
MOBILIZAÇÃO NACIONAL INDÍGENA. 2013. "Carta pública dos povos indígenas do Brasil à presidenta Dilma Rousseff durante a V Conferência Nacional de Saúde Indígena". Portal Cimi, 4 dez. Disponível em https://www.cimi.org.br/2013/12/35586/. Acesso em 10 de dezembro de 2013.

MONTEIRO, Claudemir. 2013. “Desmandos e autoritarismo marcam encontro indígena em Jacareacanga, sul do Pará". Portal Cimi, 9 ago. Disponível em https:// www.cimi.org.br/2013/08/35140/. Acesso em o9 de agosto de 2013.

\section{MOVIMENTO PASSE LIVRE SÃO PAULO.}

2013. "Carta aberta do Movimento Passe Livre São Paulo à presidenta". Blog do Movimento Passe Livre em São Paulo, 24 jun. Disponível em http://tarifazero.org/2013/06/24/carta-abertado-movimento-passe-livre-sao-paulo-apresidenta/. Acesso em 25 de junho de 2013.

\section{MOVIMENTO XINGU VIVO PARA SEMPRE.}

2013. "Munduruku protestam contra vereadores que defendem construção de hidrelétricas". Movimento Xingu Vivo para Sempre, 24 jun. Disponível em http://www.xinguvivo.org. $\mathrm{br} / 2013 / 06 / 24 /$ munduruku-protestam-contraparlamentares-que-defendem-construcao-dehidreletricas/. Acesso em 20 de janeiro de 2017.

\section{MOVIMENTO XINGU VIVO PARA SEMPRE.} 2014. "Munduruku são atacados com rojões por garimpeiros, comerciantes e prefeitura de Jacareacanga (PA)". Movimento Xingu Vivo para Sempre, 13 mai. Disponível em http://www. xinguvivo.org.br/2014/05/13/mundurukusao-atacados-com-rojoes-por-garimpeiroscomerciantes-e-prefeitura-de-jacareacangapa/. Acesso em 20 de maio de 2014.

MUNDURUKU, Lucivaldo Karo; MUNDURUKU, Eliano Kirixi. 2015. Daje Kapap Eypi.

Documentário, média-metragem. 


\section{ORGANIZAÇÃO INTERNACIONAL DO} TRABALHO (OIT). 1989. "Convenção 169: sobre povos indígenas e tribais". OIT, 7 jun. Disponível em http://www.ilo.org/brasilia/ convencoes/WCMS_236247/lang--pt/index. htm. Acesso em 18 de maio de 2016.

\section{POVO GUARANI-KAIOWÁ DE PYELITO}

KUE/MBARAKAY. 2012. "Carta da

comunidade Guarani-Kaiowá de Pyelito

Kue/Mbarakay-Iguatemi-MS para o

Governo e Justiça do Brasil". Portal

Articulação dos Povos Indígenas do Brasil

(Apib), 11 out. Disponível em http:// blogapib.blogspot.com.br/2012/10/cartada-comunidade-guarani-kaiowa-de.html. Acesso em 05 de novembro de 2012.

POVO KA'APOR. 2013. "Povo Ka'apor, do Maranhão, se solidariza à luta do povo munduruku e outros povos indígenas, contra Belo Monte". Blog Ocupação Belo Monte, 30 mai. Disponível em https://ocupacaobelomonte. wordpress.com/2013/05/30/povokaapor-do-maranhao-se-solidariza-aluta-do-povo-munduruku-e-outrospovos-indigenas-contra-belo-monte/. Acesso em 20 de julho de 2013.

\section{POVO MEBÊNGÔKRE. 2013. "Carta de} apoio à luta contra as barragens". Blog Ocupação Belo Monte, 10 mai. Disponível em https://ocupacaobelomonte.wordpress. com/2013/05/15/mebengokre-kayapo-cartade-apoio-a-luta-contra-as-barragens/. Acesso em 20 de julho de 2013.

POVO MUNDURUKU. 2013a. "Carta da assembleia extraordinária do povo Munduruku para a presidenta da República" [referente à Operação Eldorado na aldeia Teles Pires], 1 fev. Disponível em https://cimi.org.br/2013/02/34410/. Acesso em 10 de fevereiro de 2013.
POVO MUNDURUKU. 2013b. "Carta do povo Munduruku” [referente à Operação Tapajós], 27 mar. Disponível em http://xingu-vivo. blogspot.com. Acesso em 30 de março de 2013.

POVO MUNDURUKU. 2013c. "Carta do povo munduruku para a Justiça, para o Governo e para a Sociedade Mundial e os Povos Indígenas sobre a Operação Tapajós no território Munduruku", 29 mar. Disponível em https://acervo.racismoambiental. net.br. Acesso em 04 de abril de 2013. POVO MUNDURUKU. 2013d. "Carta I da ocupação de Belo Monte", 2 mai. Disponível em https://ocupacaobelomonte.wordpress. com. Acesso em 20 de novembro de 2014.

POVO MUNDURUKU. 2013e. "Carta IV da ocupação Belo Monte: o governo perdeu o juízo", 7 mai. Disponível em https:// ocupacaobelomonte.wordpress.com. Acesso em 20 de novembro de 2014.

POVO MUNDURUKU. 2013f. "Carta VII da ocupação Belo Monte: governo federal, nós voltamos", 27 mai. Disponível em https://ocupacaobelomonte.wordpress. Acesso em 20 de novembro de 2014.

\section{POVO MUNDURUKU. 2013g. "Carta IX} da ocupação Belo Monte: tragédias e barragens (a luta não acaba nem lá nem aqui)", 4 jun. Disponível em https:// ocupacaobelomonte.wordpress.com. Acesso em 15 de novembro de 2014.

POVO MUNDURUKU. 2013h. "Carta X da ocupação Belo Monte: o governo não quer nos ouvir", 11 jun. Disponível em https:// ocupacaobelomonte.wordpress.com. Acesso em 15 de novembro de 2014.

POVO MUNDURUKU. 2013i. “Declaração Munduruku: pesquisadores, não entrem nas nossas terras", 22 jun. Disponível em https:// cimi.org.br. Acesso em 25 de maio de 2016. 
POVO MUNDURUKU. 2014a. "Funai admite: interesse hidrelétrico compromete demarcação de Território Indígena". Filmagem de reunião com a presidente interina da Funai Maria Augusta Assirati. Vimeo, 17 out. Disponível em https://vimeo.com/111974175. Acesso em 10 de dezembro de 2015 .

POVO MUNDURUKU. 2014b.

"Comunicado ao Governo Brasileiro, emitido por lideranças do povo Munduruku", 3 nov. Disponível em https:// autodemarcacaonotapajos.wordpress. com. Acesso em 15 de novembro de 2014.

\section{POVO MUNDURUKU. 2014C. "Carta I}

da Autodemarcação do Território Daje

Kapap Eypi", 17 nov. Disponível em https:// autodemarcacaonotapajos.wordpress. com. Acesso em 15 de novembro de 2014.

\section{POVO MUNDURUKU. 2014d. "Carta II}

da Autodemarcação", 24 nov. Disponível em https://autodemarcacaonotapajos. wordpress.com. Acesso em 15 de novembro de 2014.

\section{POVO MUNDURUKU. 2014e. "Carta III} da Autodemarcação", 28 nov. Disponível em https://autodemarcacaonotapajos. wordpress.com. Acesso em 15 de novembro de 2014.

POVO MUNDURUKU. 2015a. "Protocolo de Consulta Munduruku”, 15 jul.

Disponível em https://reporterbrasil. org.br/wp-content/uploads/2016/07/ Protocolo-de-consulta-Munduruku. pdf. Acesso em 20 de maio de 2018.
POVO MUNDURUKU. 2015b. "Carta dos Munduruku em apoio aos Guerreiros GuaraniKaiowá, Guerreiros Ka'apor e a todos os guerreiros indígenas do país", 15 jul. Disponível em https://autodemarcacaonotapajos. wordpress.com. Acesso em: 22 de julho de 2015.

POVO MUNDURUKU. 2016. Autodemarcação Daje Kapap Eipi. Cartilha. Mimeografado.

SANTANA, Renato. 2013a. "Caciques e lideranças munduruku denunciam intervenção do governo federal para forçar construção de usina". Portal Cimi, 9 ago. Disponível em www. cimi.org.br. Acesso em 12 de setembro de 2017.

SANTANA, Renato. 2013b. “Governo federal quebra acordo com povo munduruku e operação militar se movimenta em Jacareacanga". Portal Cimi, 12 ago. Disponível em www.cimi. org.br. Acesso em: 02 de julho de 2018.

SANTANA, Renato. 2013c. "Aldeia Munduruku é invadida por Força Nacional no sul do Pará". Brasil de Fato, 6 set. Disponível em https:// www.brasildefato.com.br/node/25813/. Acesso em 06 de maio de 2017.

SANTANA, Renato. 2013d. "Aldeia Munduruku é invadida por Força Nacional e cacique geral convoca assembleia". Portal Cimi, 6 set. Disponível em https:// www.cimi.org.br/2013/09/35260/. Acesso em 10 de maio de 2015.

SAUD, Larissa. 2014․ "No Pará, indígenas apreendem máquinas e expulsam garimpeiros". Terra Magazine, 3 fev. Disponível em http:// terramagazine.terra.com.br/blogdaamazonia/ blog/2014/02/03/no-para-indigenasapreendem-maquinas-e-expulsamgarimpeiros/. Acesso em 10 de maio de 2016. 
SAUD, Larissa. 2014b. “Munduruku ocupam Jacareacanga por recontratação de professores". Movimento Xingu Vivo para Sempre, 7 mai. Disponível em http:// www.xinguvivo.org.br/2014/05/07/ munduruku-ocupam-jacareacangapor-recontratacao-de-professores/. Acesso em 10 de maio de 2014.

SECRETARIA-GERAL DA PRESIDÊNCIA DA REPÚBLICA. 2013. "Esclarecimentos sobre a consulta aos Munduruku e a invasão de Belo Monte". Portal Secretaria Ceral da Presidência da República, 6 mai. Disponível em www.secretariageral.gov.br/ noticias/ultimas_noticias/2013/05/06-052013-esclarecimentos-sobre-a-consultaaos-munduruku-e-a-invasao-de-belomonte1/4. Acesso em o3 de maio de 2017.
SENA, Ediberto. 2013. "Tapajós: vendo o dilúvio chegar". Instituto Humanitas Unisinos/Adital, 15 fev. Disponível em http://www.ihu.unisinos. br/noticias/517594-mais-uma-materia-deum-noe-vendo-o-diluvio-chegar-e-o-povodancando-carnaval-artigo-de-edilbertosena. Acesso em 10 de junho de 2017.

SIQUEIRA, Ruben. 2017. "O aumento da violência no campo tem a cara do golpe". Le Monde Diplomatique, 25 mai. Disponível em http://diplomatique.org.br/o-aumentoda-violencia-no-campo-tem-a-cara-dogolpe/. Acesso em 25 de maio de 2017.

SPOSATI, Rui. 2013. "Munduruku expulsam pesquisadores de terra indígena". Portal Cimi, 22 jun. Disponível em http://www.cimi.org. $\mathrm{br} / \mathrm{site} / \mathrm{pt}-\mathrm{br} /$ ?system=news\&conteudo_ $\mathrm{id}=6990$ \&action=read. Acesso em 20 de janeiro de 2017.

Recebido em 19 de setembro de 2019. Aceito em 14 de janeiro de 2020. 